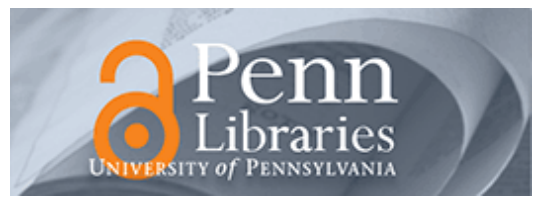

University of Pennsylvania

ScholarlyCommons

Accounting Papers

Wharton Faculty Research

$9-2012$

\title{
Why Do Pro Forma and Street Earnings not Reflect Changes in GAAP? Evidence From SFAS 123R
}

Mary E. Barth

Ian D. Gow

Daniel J. Taylor

University of Pennsylvania

Follow this and additional works at: https://repository.upenn.edu/accounting_papers

Part of the Accounting Commons

\section{Recommended Citation}

Barth, M. E., Gow, I. D., \& Taylor, D. J. (2012). Why Do Pro Forma and Street Earnings not Reflect Changes in GAAP? Evidence From SFAS 123R. Review of Accounting Studies, 17 (3), 526-562. http://dx.doi.org/ 10.1007/s11142-012-9192-9

This paper is posted at ScholarlyCommons. https://repository.upenn.edu/accounting_papers/6

For more information, please contact repository@pobox.upenn.edu. 


\title{
Why Do Pro Forma and Street Earnings not Reflect Changes in GAAP? Evidence From SFAS 123R
}

\author{
Abstract \\ This study examines how key market participants-managers and analysts-responded to SFAS 123R's \\ controversial requirement that firms recognize stock-based compensation expense. Despite mandated \\ recognition of the expense, some firms' managers exclude it from pro forma earnings and some firms' \\ analysts exclude it from Street earnings. We find evidence consistent with managers opportunistically \\ excluding the expense to increase earnings, smooth earnings, and meet earnings benchmarks but no \\ evidence that these exclusions result in an earnings measure that better predicts future firm performance. \\ In contrast, we find that analysts exclude the expense from earnings forecasts when exclusion increases \\ earnings' predictive ability for future performance and that opportunism generally does not explain \\ exclusion by analysts incremental to exclusion by managers. Thus our findings indicate that opportunism \\ is the primary explanation for exclusion of the expense from pro forma earnings and predictive ability is \\ the primary explanation for exclusion from Street earnings. Our findings suggest the controversy \\ surrounding the recognition of stock-based compensation expense may be attributable to cross-sectional \\ variation in the relevance of the expense for equity valuation, as well as to differing incentives of market \\ participants.
}

\section{Keywords}

stock-based compensation, SFAS 123R, non-GAAP earnings, street earnings, pro forma earnings, earnings forecast exclusions, incentives

Disciplines

Accounting 


\title{
Why Do Pro Forma and Street Earnings Not Reflect Changes in GAAP? Evidence from SFAS 123R
}

\author{
Mary E. Barth \\ Graduate School of Business \\ Stanford University \\ mbarth@stanford.edu \\ Ian D. Gow \\ Harvard Business School \\ igow@hbs.edu \\ Daniel J. Taylor \\ The Wharton School \\ University of Pennsylvania \\ dtayl@wharton.upenn.edu
}

November 2011

We thank David Aboody, Tom Lys, Robert Magee, Sarah McVay, Richard Sloan (editor), workshop participants at the American Accounting Association annual meeting, especially discussant Valentina Zamora, the Financial Accounting and Reporting Section midyear meeting, especially discussant Melissa Lewis, the Kellogg School of Management, Lancaster University, Santa Clara University, Stanford University, and University of Southern California, and two anonymous reviewers for helpful comments and suggestions. We thank our respective schools for financial support. 


\title{
Why Do Pro Forma and Street Earnings Not Reflect Changes in GAAP? Evidence from SFAS 123R
}

\begin{abstract}
This study examines how key market participants-managers and analysts—responded to SFAS 123R's controversial requirement that firms recognize stock-based compensation expense. Despite mandated recognition of the expense, some firms' managers exclude it from pro forma earnings and some firms' analysts exclude it from Street earnings. We find evidence consistent with managers opportunistically excluding the expense to increase earnings, smooth earnings, and meet earnings benchmarks, but no evidence that such exclusion results in an earnings measure that better predicts future firm performance. In contrast, we find that analysts exclude the expense from earnings forecasts when the exclusion increases earnings' predictive ability for future performance, and opportunism generally does not explain exclusion by analysts incremental to exclusion by managers. Thus, our findings indicate that opportunism is the primary explanation for exclusion of the expense from pro forma earnings and predictive ability is the primary explanation for exclusion from Street earnings. Our findings suggest the controversy surrounding the recognition of stock-based compensation expense may be attributable to cross-sectional variation in the relevance of the expense for equity valuation, as well as to differing incentives of market participants.
\end{abstract}

JEL Classification: G10; M4; M41; M43; M45

Keywords: stock-based compensation; SFAS 123R; non-GAAP earnings; Street earnings; pro forma earnings; earnings forecast exclusions; incentives 


\section{Why Do Pro Forma and Street Earnings Not Reflect Changes in GAAP? Evidence from SFAS 123R}

\section{Introduction}

Even though Generally Accepted Accounting Principles (GAAP) define the measure of earnings included in mandatory disclosures and filings with the US Securities and Exchange Commission (SEC), the use of earnings measures that do not conform to GAAP by managers and analysts has increased in recent years. Many firms present and refer to measures of earnings that exclude some earnings components, popularly referred to as "pro forma earnings." Similarly, analysts are not constrained in the definition of earnings that they forecast, and the definition of forecasted earnings, popularly referred to as "Street earnings," often varies across firms and analysts. The prevalence and increasing use of these non-GAAP earnings measures are of concern to securities market regulators. ${ }^{1}$ Reflecting this concern, the Sarbanes-Oxley Act of 2002 contains provisions related to firms' use of non-GAAP earnings in their earnings announcements. In particular, Section 401(b) of the Act required the SEC to issue rules requiring firms to reconcile any non-GAAP financial measure to the most directly comparable GAAP financial measure. Regulation G, put into effect by the SEC in 2003, now governs firms' disclosure of non-GAAP financial measures, such as pro forma earnings.

This paper seeks to provide evidence on reasons for exclusions from pro forma and Street earnings, with particular emphasis on the properties of the excluded items and any differences between analysts and managers' reasons for exclusion. We address these questions in the

\footnotetext{
${ }^{1}$ The SEC describes the concern as relating to "the improper use of non-GAAP financial measures during the past 30 years." Former SEC Chief Accountant Turner, stated "people use these 'pro-forma' press releases as a vehicle to spin the investors" (Turner, as quoted in Stamas, "SEC looks into firms' earnings releases 'Pro-forma' figures may mislead investors," The Seattle Times, June 19, 2001). More recently, the SEC has referred to pro forma earnings as a fraud risk factor (Leone, "What's on the SEC's Radar?" CFO.com, September 29, 2010).
} 
context of the recent change in the definition of GAAP earnings related to stock-based compensation expense. We focus on this setting for a number of reasons. First, stock-based compensation expense is clearly a recurring item, which makes it possible for analysts to exclude it from forecasts ex ante, i.e., prior to observing realized earnings. Second, there is substantial disagreement between analysts and managers on whether stock-based compensation expense should be excluded - analysts only exclude it in $27 \%$ of cases in which managers exclude it, which makes it a powerful setting in which to examine differences in the reasons for exclusion from Street and pro forma earnings. Finally, because stock-based compensation expense was disclosed prior to recognition, we are able to estimate properties of the expense independent of the decision to exclude it.

In addition, accounting for stock-based compensation is one of the most controversial topics ever addressed by accounting standard setters. In 1995, despite its unanimous view that the expense should be recognized, the Financial Accounting Standards Board (FASB) yielded to political pressure in making recognition voluntary in Statement of Financial Accounting Standard No. 123 (FASB, 1995). In light of the accounting scandals of 2001 and 2002 and the International Accounting Standards Board's then-recent decision to require expense recognition for firms applying its standards, in 2004 the FASB issued SFAS 123R (FASB, 2004), which requires recognition of stock-based compensation expense beginning in $2006 .^{2}$ However, SFAS 123R faced resistance similar to that encountered by SFAS 123, suggesting that, despite the FASB's conceptual arguments, many still disagree with recognition of stock-based compensation expense. Consistent with ongoing controversy, for some firms, managers present measures of

\footnotetext{
${ }^{2}$ Throughout, stock-based compensation expense refers to the portion of stock-based compensation expense that was not required to be recognized prior to the issuance of SFAS 123R. This expense relates primarily to at-themoney stock options granted to employees.
} 
net income in earnings announcements (pro forma earnings) that exclude stock-based compensation expense and, for some firms, analyst consensus earnings forecasts (Street earnings) exclude the expense. In addition, for a given firm, managers and analysts do not always treat the expense in the same way.

We test two explanations identified in prior research for exclusion of expenses from pro forma and Street earnings. The first, which we label the "opportunism" explanation, is that exclusion is motivated by the desire to manage investors' perceptions of firm performance. The second, which we label the "predictive ability" explanation, is that excluded items are not useful in predicting future firm performance and, thus, excluding them results in an earnings measure that is more useful for predicting future firm performance.

We expect that opportunism is more likely to explain managers' exclusion of stock-based compensation expense from pro forma earnings, and that predictive ability is less likely to explain this exclusion. As noted above, Regulation $\mathrm{G}$ is evidence of concerns of the SEC that firms use pro forma earnings to manage investors' perceptions about the firm. Thus, we expect that managing investors' perceptions is the primary motivation for managers' exclusion decisions.

We expect that both opportunism and predictive ability explain analysts' exclusion of stock-based compensation expense from Street earnings. However, drawing on prior research, we predict that that opportunism explanation primarily reflects the incentives of managers and conjecture that, once the exclusion decisions of managers are controlled for, opportunism does not incrementally explain exclusion by analysts.

We conduct our tests using a sample comprising all firms with required data in industries with at least one firm whose consensus analyst earnings forecast for 2006, the first year expense 
recognition was required by SFAS 123R, excludes stock-based compensation expense. We refer to firms with stock-based compensation expense excluded from (included in) 2006 Street earnings as Street Excluders (Street Includers), and firms with the expense excluded from (included in) 2006 pro forma earnings as Pro Forma Excluders (Pro Forma Includers).

To test the opportunism explanation, we test whether incentives to increase earnings, smooth earnings, and meet earnings benchmarks explain whether a firm is a Pro Forma Includer or Excluder and whether a firm is a Street Excluder or Includer. To allow for the possibility that Street earnings exclusion is explained by analysts following the pro forma exclusion or inclusion decision of managers, or vice versa, in the Street earnings relation we also control for whether the expense was excluded from pro forma earnings, and in the pro forma earnings relation we control for whether the expense was excluded from Street earnings. Because we expect that opportunism is more likely to explain pro forma exclusion and less likely to explain Street exclusion, we expect opportunism to explain pro forma exclusion incrementally to Street exclusion, but do not expect opportunism to explain Street earnings exclusion incrementally to pro forma exclusion.

We test the predictive ability explanation in two ways, both using data from years that predate the expense recognition requirements of SFAS 123R, which ensures that the estimated predictive ability is not influenced by the exclusion decision. First, we test which earnings measure better predicts future earnings, a measure that excludes stock-based compensation expense or a measure that includes it. We conduct this test separately for four groups of firms, Pro Forma Excluders, Pro Forma Includers, Street Excluders, and Street Includers. We expect that the earnings measure that excludes (includes) stock-based compensation expense has more predictive ability for Street Excluders (Street Includers). However, we do not expect that the 
earnings measure that excludes (includes) stock-based compensation expense has more predictive ability for Pro Forma Excluders (Pro Forma Includers). Second, we estimate the relation between stock-based compensation expense and future earnings, permitting the relation to differ for Street Excluders and Includers. We expect stock-based compensation expense to be significantly related to future earnings for Street Includers, and that this relation is significantly attenuated or absent for Street Excluders. We estimate the same relation for Pro Forma Excluders and Includers, but expect no difference in the relation for these two groups of firms.

The findings are consistent with our predictions. Regarding pro forma earnings, we find support for the opportunism explanation and no support for the predictive ability explanation. In particular, we find that incentives to increase earnings, meet earnings benchmarks, and smooth earnings explain pro forma exclusion of stock-based compensation expense. We do not find that pro forma exclusion is associated with greater predictive ability. In fact, we find the oppositeearnings that includes (excludes) stock-based compensation expense has significantly greater predictive ability for firms whose pro forma earnings excludes (includes) the expense. Regarding Street earnings, we find support for the predictive ability explanation, but limited support for the opportunism explanation. In particular, we find that earnings that excludes (includes) stock-based compensation expense has significantly greater predictive ability for firms whose Street earnings excludes (includes) the expense. Although we also find that incentives to increase earnings, meet earnings benchmarks, and smooth earnings explain Street exclusion unconditionally, their associations generally are not significant after controlling for exclusion from pro forma earnings. These findings suggest that analysts are concerned with managing investor perceptions of firm performance only to the extent that management is. The opportunism explanation does not explain exclusion by analysts incremental to exclusion by 
managers.

Additional analyses indicate that our (i) predictive ability findings are not attributable to an association between predictive ability and opportunism, and are robust to measuring future firm performance using cash from operations; (ii) inferences apply to firms in both the computer industry—which includes many of the Street Excluders in our sample—and non-computer industries; (iii) inferences are robust to using an alternative source to identify Street Excluders; and (iv) findings are not attributable to modifications in stock option plans in anticipation of mandatory recognition of stock-based compensation expense.

We contribute to the literature on non-GAAP earnings by showing that different incentives explain exclusion of an earnings component from pro forma earnings and Street earnings. Also, ours is the first study to test whether the predictive ability for future performance of a particular earnings component differs for firms whose managers (analysts) exclude it from pro forma (Street) earnings and for firms whose managers (analysts) include it. A key distinguishing feature of our study that permits these contributions is that we focus on a change in the definition of GAAP earnings. This enables us to test our predictions using a sample that includes not only firms whose managers and analysts exclude stock-based compensation expense from pro forma and Street earnings, but also firms whose managers and analysts include the expense. That is, we observe stock-based compensation expense regardless of the exclusion decision, whereas prior research examines the properties of special items defined as items that are excluded from pro forma or Street earnings. Prior research compares the predictive ability of, and to a more limited extent incentives related to, excluded earnings components with that of other, potentially quite different, included earnings components using samples comprising only firms that have excluded a component from one or both measures. 
We contribute to the literature on accounting for stock-based compensation by showing that stock-based compensation expense does not have the same predictive ability for future performance for all firms. Also, we provide insight into how key market participants respond to changes in GAAP. Our findings suggest that, regardless of the correctness of recognizing stockbased compensation expense from the standpoint of the FASB's conceptual framework, analysts ignore a change in GAAP when doing so yields an earnings measure that better predicts future firm performance. We find no evidence that managers do the same when determining pro forma earnings; rather, the findings reveal managers respond to incentives to increase earnings, smooth earnings, and meet earnings benchmarks. Our findings suggest the controversy surrounding recognition of stock-based compensation expense may be attributable to cross-sectional variation in the relevance of the expense for equity valuation, as well as to differing incentives of key market participants.

The remainder of the paper is as follows. Sections 2 and 3 provide institutional background and discuss related research on accounting for stock-based compensation, and pro forma and Street earnings. Section 4 develops our predictions and research design. Section 5 describes the sample and data, and section 6 presents the results. Section 7 concludes.

\section{Accounting for Stock-based Compensation}

\subsection{Institutional background}

Accounting for stock-based compensation is one of the most controversial topics ever addressed by accounting standard setters. Accounting Principles Board Opinion No. 25 (APB $25 ; 1973)$ was the initial standard specifying how to account for stock options granted to employees as compensation. APB 25, which predates Black and Scholes (1973), required firms 
to measure the expense as the difference between the stock price and the option exercise price on the grant date. This amount equals zero for most employee options. In 1984, the FASB added a project to its agenda to improve the requirements in APB 25. That project resulted in the FASB issuing an exposure draft in 1993 proposing that firms measure the expense based on the options' grant date value. The exposure draft met with fierce resistance by firms, and the U.S. Congress held hearings on whether the FASB should be permitted to finalize the standard with the proposed measurement requirement.

In 1995 the FASB issued SFAS 123 (FASB, 1995). Although SFAS 123 recommended measurement of the expense using the grant date value approach, it permitted firms to recognize the expense using the measurement approach of APB 25 and only disclose what net income would have been had the expense been measured using the grant date value approach. The Basis for Conclusions of SFAS 123 (FASB, 1995, I[57-62) explains that even though the FASB was unanimous in its view that expense recognition based on grant date values was proper accounting, the FASB did not require expense recognition because the controversy was so severe that doing so would have threatened accounting standard setting in the private sector.

Almost all firms applied the measurement approach of APB 25 until the summer of 2002, when a small number of firms adopted the grant date value approach (Aboody, Barth, and Kasznik, 2004b; Brown and Lee, 2006). In light of the financial reporting failures of 2001, the FASB revisited accounting for stock-based compensation and, in 2004, the FASB issued SFAS 123R (FASB, 2004), which took effect for fiscal years beginning on or after June 15, 2005. The primary effect of SFAS $123 \mathrm{R}$ was to require recognition of stock-based compensation expense using the grant date value measurement approach. Despite the apparent resolution in SFAS 123R, the controversy continues. Several prominent persons, including three Nobel Laureates 
and former U.S. Secretaries of State and the Treasury, recently reiterated arguments that recognizing the expense is improper because the value of employee stock options does not represent an expense of the firm (Hagopian, 2006), and filed a petition with the SEC in 2008 alleging that the SEC failed in its duties by permitting the FASB to issue SFAS $123 \mathrm{R}^{3}$

\subsection{Related stock-based compensation research}

Our study relates to two streams of literature on the accounting for stock-based compensation. This first is the literature that examines actions taken in anticipation of or in response to the FASB's requirement to recognize stock-based compensation expense. Aboody, Barth, and Kasznik (2004b) finds that firms voluntarily recognize the expense in 2002 and early 2003 to signal greater financial reporting transparency. ${ }^{4}$ Relating to non-accounting actions that reduce the income effect of mandated expense recognition, Carter and Lynch (2003) finds that firms manage the timing of option repricings, Choudhary, Rajgopal, and Venkatachalam (2009) finds that some firms accelerated vesting of employee options, and Brown and Lee (2006) and Johnston and Rock (2006) find that firms reduce their use of option-based compensation. We contribute to this literature by examining financial reporting actions taken by key market participants-managers and analysts-in response to SFAS $123 \mathrm{R}$.

The second is the literature linking stock-based compensation expense and firm fundamentals. Aboody (1996) and Aboody, Barth, and Kasznik (ABK, 2004a) find a significant negative relation between changes in unrecognized stock-based compensation expense and stock

\footnotetext{
3 "Petition for Review and Repeal of FAS 123R, 'Share-Based Payment" filed with the SEC by opponents of SFAS 123R on February 27, 2008.

${ }^{4}$ Consistent with similar motivations for voluntary expense recognition and inclusion of the expense in earnings forecasts, stock-based compensation expense is included in consensus forecasts of all firms McConnell et al. (2003) identifies as voluntarily recognizing the expense. As section 5 explains, we exclude from our sample all firms that voluntarily recognized the expense. We are unaware of any of firms that included unrecognized stock-based compensation expense in pro forma earnings prior to 2006.
} 
returns. Hanlon, Rajgopal, and Shevlin (2003) finds a significant positive relation between stock-based compensation expense for the firm's top five executives and future operating earnings, although the sign of the relation depends on the specification (Larcker, 2003). However, prior research does not examine cross-sectional variation in the predictive ability of stock-based compensation expense for firm fundamentals, which could be one source of the continuing debate about accounting for stock-based compensation. For example, firms for which stock-based compensation expense has no predictive ability might question whether the expense should be a component of earnings, whereas firms for which the expense has predictive ability might not. We contribute to this literature by investigating whether the predictive ability of stock-based compensation expense differs for firms whose pro forma earnings excludes and includes the expense, and for firms whose Street earnings excludes and includes the expense.

\section{Pro Forma and Street Earnings}

\subsection{Institutional background}

Many firms present "pro forma" measures of net income in earnings announcements that exclude some earnings components, typically expenses. The prevalence of these non-GAAP earnings measures has increased in recent years, causing concern among securities market regulators. Reflecting this concern, the Sarbanes-Oxley Act of 2002 contains provisions related to firms' use of non-GAAP earnings. In particular, Section 401(b) of the Act requires the SEC to issue rules requiring firms to reconcile a disclosed non-GAAP financial measure to the most directly comparable GAAP financial measure. The SEC put this requirement into effect in Regulation G (effective March 28, 2003). Pro forma earnings (earnings per share) is a nonGAAP measure for which earnings (earnings per share) is the most directly comparable GAAP measure. Stock-based compensation expense is an example of an earnings component that firms 
exclude from pro forma earnings.

"Street earnings" refers to earnings forecasts or actual earnings as tracked by major data services that collect and aggregate analyst forecasts, such as First Call-I/B/E/S. ${ }^{5}$ These data services do not prescribe which items are to be included in or excluded from forecasted earnings (Jones, 2006). Rather, analysts covering the firm collectively determine the definition of a firm's Street earnings. In particular, for an analyst's earnings forecast to be included in the consensus calculation, the forecast must be calculated on the same basis as that used by the majority of analysts issuing forecasts for the firm (First Call, 1999; Lambert, 2004). Consistent with this policy, the consensus earnings forecast of a firm on First Call-I/B/E/S includes or excludes stock-based compensation expense depending on how the expense is treated in the forecasts of the majority of analysts covering the firm. ${ }^{6}$

Consistent with prior research, we refer to differences between GAAP earnings and either pro forma earnings or Street earnings as "exclusions" because the differences typically represent components of GAAP earnings excluded from pro forma earnings or Street earnings.

\subsection{Related pro forma and Street earnings research}

A large literature addresses differences between GAAP earnings and Street or pro forma earnings. Earlier studies in this literature focus on the association between pro forma or Street

\footnotetext{
${ }^{5}$ I/B/E/S and First Call are data services of Thomson Financial that similarly treat actual earnings and analyst earnings forecasts. Thus, we refer to them collectively as First Call-I/B/E/S except when discussing our data sources; First Call and I/B/E/S maintain separate databases. All data used in this study are taken from the I/B/E/S historical research database, with exception of footnote data, which are taken from the First Call database.

${ }^{6}$ Consistent with this, Zacks, another supplier of analyst earnings forecasts, includes stock-based compensation expense in all forecasts in its database; if the forecast submitted by the analyst excludes the expense, Zacks adjusts the forecast to include it. See, Wall Street Journal Online, Options Expensing Jars Consensus, April 4, 2006. Because stock-based compensation expense is not a "special" or transitory item, the forecast data provider can more readily determine whether stock-based compensation expense is included in a particular analyst's forecast made prior to observing actual earnings. This determination is more difficult for special or transitory items examined in prior research. This is because these items, almost by definition, should have an expectation of zero, which means there is no practical difference between forecasting the item to be zero and excluding the item from the forecast. Thus, such items are only meaningfully excluded after actual earnings are observed.
} 
earnings and stock returns. Bhattacharya et al. (2003) finds that pro forma and Street earnings both are more highly associated with earnings announcement returns than is operating earnings as defined by Standard and Poor's (S\&P). Lougee and Marquardt (2004) also finds that pro forma earnings is more highly associated with earnings announcement stock returns than is GAAP earnings in some circumstances, but finds mixed evidence regarding the predictive ability of pro forma earnings for future profitability and future returns. Bradshaw and Sloan (2002) finds that the explanatory power of Street earnings for stock returns is greater than that of GAAP earnings after 1992, when differences between GAAP and Street earnings became more prevalent. ${ }^{7}$ Consistent with these findings, Brown and Sivakumar (2003) finds that Street earnings is more highly associated with stock price and three- and sixty-three day returns than is S\&P operating earnings. ${ }^{8}$

A limitation of studies examining stock returns is that a motivation for firms to use pro forma earnings is to manage investors' perceptions about the firm and, thus, it is possible investors are misled by pro forma earnings (e.g., Doyle, Lundholm, and Soliman, 2003). Lougee and Marquardt (2004) explains that firms strategically exclude items from pro forma earnings to influence investors' perceptions of the earnings news. As a result, returns reflect investors' reactions to firms' strategic exclusion behavior as well as the predictive ability of the excluded items, which confounds inferences obtained from stock return tests. Thus, some studies, as does ours, instead test whether an excluded item has predictive ability for future firm performance. For example, Doyle, Lundholm, and Soliman (2003) finds that exclusions from Street earnings

\footnotetext{
${ }^{7}$ However, Cohen, Hann, and Ogneva (2007) finds that the increased explanatory power of Street earnings is attributable to measurement error in earnings surprises.

${ }^{8}$ Brown and Sivakumar (2003) observes that comparing GAAP earnings and Street earnings biases in favor of Street earnings because GAAP earnings is not designed to measure recurring operating earnings, which is more the motivation for Street earnings. Because operating earnings is not defined by GAAP, as does Bhattacharya et al. (2003), Brown and Sivakumar (2003) studies operating earnings as defined by S\&P.
} 
have significant predictive ability for future operating cash flows and earnings, but their

predictive ability is less than that of GAAP earnings. ${ }^{9}$

A few studies examine how pro forma and Street earnings differ from each other. Gu and Chen (2004) compares the predictive ability of items excluded from both pro forma and Street earnings with that of items excluded from pro forma earnings but included in Street earnings. $\mathrm{Gu}$ and Chen (2004) finds that both types of pro forma exclusions have predictive ability for future operating cash flows and earnings, but the relations are weaker for items excluded from both pro forma and Street earnings. Baik, Farber, and Petroni (2009) adopts the approach in Gu and Chen (2004) and tests for cross-sectional differences in the predictive ability of items excluded from both pro forma and Street earnings. Baik, Farber, and Petroni (2009) finds that such expense exclusions help predict future earnings for glamour firms, but not for value firms, and infers that analysts' incentives influence Street earnings, which leads to Street earnings that are less useful in predicting future earnings for glamour stocks. ${ }^{10}$ Both studies examine how analysts respond to firms' exclusions from pro forma earnings, i.e., they study exclusions from Street earnings conditional on the item being excluded from pro forma earnings. They do not seek to test what explains the pro forma exclusion. ${ }^{11}$

We contribute to this literature by testing whether the predictive ability of a particular

\footnotetext{
${ }^{9}$ Landsman, Miller, and Yeh (2007) obtains similar inferences using tests of predictive ability based on the Ohlson $(1995,1999)$ valuation model.

${ }^{10}$ A large portion of firms in our sample with stock-based compensation expense excluded from Street earnings are in the computer industry. Such firms might be considered glamour firms. The glamour firm findings in Baik, Farber, and Petroni (2009) suggest that excluded stock-based compensation expense would have predictive ability for these firms. We find the opposite, which suggests that our findings are not explained by the glamour firm effect in Baik, Farber, and Petroni (2009).

${ }^{11}$ Lougee and Marquardt (2004) uses firms' earnings response coefficients and corresponding $\mathrm{R}^{2} \mathrm{~s}$ to explain the likelihood that a firm subsequently reports pro forma earnings. However, as in other related research, Lougee and Marquardt (2004) compares predictive ability only for firms with pro forma exclusions and does not consider whether cross-sectional differences in an item's predictive ability explain its exclusion. Curtis et al. (2011) tests the opportunism and predictive ability explanations for net positive special items by confirming that the items have less predictive ability for future operating earnings than past operating earnings and documenting no association between the items and earnings announcement returns.
} 
item—stock-based compensation expense- differs for firms whose analysts include it in Street earnings and for firms whose analysts exclude it, and we do the same for pro forma earnings. Also, we test the extent to which the predictive ability and opportunism explanations explain pro forma and Street exclusions. We provide evidence that different incentives explain exclusion of an earnings component from these two earnings measures-we find that opportunism explains exclusion from pro forma earnings and predictive ability explains exclusion from Street earnings.

\section{Empirical Predictions and Research Design}

\subsection{Opportunism and predictive ability}

Prior literature (e.g., Doyle, Lundholm, and Soliman, 2003) and the concerns of Congress and the SEC leading up to promulgation of Regulation G suggest two explanations for exclusion of an earnings component from pro forma or Street earnings. The opportunism explanation predicts managers and analysts opportunistically exclude components of earnings from pro forma or Street earnings, i.e., exclude components when doing so helps firms to meet benchmarks or has a positive effect on valuation metrics, such as earnings. The predictive ability explanation predicts managers and analysts exclude earnings components that are less predictive of future firm performance.

One issue in developing separate empirical predictions for Street and pro forma earnings based on prior research is that much of this research has generally either not sought, or has not been able, to distinguish the roles of managers and analysts in exclusion decisions. Nonetheless, we believe that prior research provides evidence suggesting that opportunism is the primary explanation for pro forma exclusion and predictive ability is the primary explanation for Street exclusion. This evidence is consistent with investors' perceptions of firm performance being of greater concern to managers than to analysts, and with analysts being more concerned than 
managers about predicting firm performance.

Regarding pro forma earnings, evidence from prior research and regulatory actions suggests that opportunism is the primary explanation for exclusion. Recent regulatory changes, e.g., Regulation G, are aimed at addressing concerns of the SEC that firms use pro forma earnings to manage investors' perceptions about the firm. Similarly, there is considerable evidence of managers acting opportunistically in determining pro forma earnings (Doyle, Lundholm, and Soliman, 2003; Lougee and Marquardt, 2004; McVay, 2006; Brown et al., 2011), but relatively little evidence of managers' choices reflecting predictive ability. Studies that find evidence of managers' exclusion decisions reflecting predictive ability (or similar notions, such as value relevance) often do so in settings in which it is difficult to rule out opportunism as an alternative explanation. For example, consistent with a predictive ability explanation, Lougee and Marquardt (2004) finds that firms with low GAAP earnings informativeness are more likely to disclose pro forma earnings. However, Lougee and Marquardt (2003) also finds that firms with more informative GAAP earnings exclude items that do not have predictive ability, and that opportunism has more explanatory power than earnings informativeness. Also consistent with a predictive ability explanation, Blacconiere et al. (2010) suggests that managers' disavowal of the measurement of stock-based compensation expense reflects legitimate concerns about the reliability of value estimates, and finds limited evidence of opportunism. Riedl and Srinivasan (2010) finds evidence that the presentation of special items on the income statement or in the footnotes is affected by the predictive ability of the item, but prior research suggests that even the identification of an item as "special" often reflects opportunistic motivations (Riedl, 2004). With regard to Street earnings, we expect that both opportunism and predictive ability explain analysts' exclusion of stock-based compensation expense. However, we predict that the 
opportunism explanation primarily reflects the incentives of managers and that, once the exclusion decisions of managers are controlled for, opportunism has either no role, or a diminished role, in explaining exclusion by analysts. Consistent with the predictive ability explanation, prior research (discussed in section 3.2) finds that items excluded from Street earnings have less predictive ability for firm fundamentals than either GAAP earnings or earnings components that are excluded from pro forma earnings, but included in Street earnings (Gu and Chen 2004). These findings are consistent with predictive ability explaining Street exclusion to a greater extent than pro forma exclusion. Baik, Farber, and Petroni (2009), one of the few studies that examines the opportunism explanation for exclusions by analysts, identifies optimism "in order to generate more investment banking business" (p. 50) as one of the key motivations for opportunistic exclusion by analysts. However, consistent with a diminished role for opportunism in explaining analyst exclusion incremental to manager exclusion, Christensen et al. (2011) shows that managers exclude recurring earnings components, such as stock-based compensation expense, in an attempt to influence analysts to exclude the components. To the extent that opportunism is the primary motivation for exclusions by managers and not by analysts, we expect that, after controlling for exclusion by managers, opportunism has little or no incremental explanatory power for Street exclusion.

\subsection{Opportunism}

To test the opportunism explanation, we estimate two versions of equation (1) using probit regression.

$$
\begin{aligned}
E X= & \beta_{0}+\beta_{1} \text { COMPXA }+\beta_{2} I P O S S U R P+\beta_{3} I L O S S+\beta_{4} \sigma(C O M P X A)+\beta_{5} \sigma(A F) \\
& +\beta_{6} \text { ANALYSTS }+\beta_{7} \text { INSTIT }+\beta_{8} P O L I C Y+\beta_{9} R O A+\beta_{10} \text { SIZE }+\varepsilon
\end{aligned}
$$

In the first (second) version, EX is EX_PROFORMA (EX_STREET), where EX_PROFORMA 
(EX_STREET) is an indicator variable that equals one if the firm's pro forma (Street) earnings for fiscal 2006 excludes stock-based compensation expense, and zero otherwise. We label firms with EX_PROFORMA equal to one (zero) as Pro Forma Excluders (Pro Forma Includers), and firms with EX_STREET equal to one (zero) as Street Excluders (Street Includers).

To estimate equation (1) we use 2005 amounts because these are the most recent data available prior to issuance of 2006 earnings forecasts. As a result, all variables in equation (1) predate the effective date of SFAS $123 \mathrm{R}$ and the consequent decision of whether analyst forecasts or firms' pro forma earnings include or exclude stock-based compensation expense. For reasons explained below, we expect $\beta_{1}, \beta_{2}, \beta_{3}$, and $\beta_{4}$ are positive and $\beta_{8}$ is negative in both versions of equation (1); we have no expectation regarding the signs of $\beta_{5}, \beta_{6}, \beta_{7}, \beta_{9}$, and $\beta_{10}$.

The first four explanatory variables in equation (1) are proxies for incentives to exclude stock-based compensation expense from pro forma earnings. COMPXA is stock-based compensation expense, $C O M P X$, deflated by beginning of year total assets. ${ }^{12} \mathrm{We}$ expect that firms with higher stock-based compensation expense are more likely to exclude the expense from pro forma earnings because the effect of exclusion on related valuation metrics is greater when the expense is higher. IPOSSURP is an indicator variable that equals one if actual earnings per I/B/E/S minus the last consensus earnings forecast before the firm's fiscal 2005 year-end is positive, and zero otherwise. Based on Kasznik and McNichols (2002), we expect firms that have met earnings benchmarks in the past have a greater incentive to do so in the future and, thus, expect a positive relation between IPOSSURP and exclusion of stock-based compensation expense.

\footnotetext{
${ }^{12}$ For a few firms we confirmed that Compustat data \#399, our measure of COMPX, is the difference, per share, between GAAP net income and what net income would have been had stock-based compensation expense been measured using the grant date value measurement approach disclosed under SFAS 123. COMPX reflects the amount by which earnings that excludes the expense is higher than earnings that includes it.
} 
ILOSS is an indicator variable that equals one if excluding stock-based compensation expense results in the firm avoiding a loss, i.e., $N I-C O M P X<0<N I$, where $N I$ is actual earnings as reported by I/B/E/S, and zero otherwise. Because Burgstahler and Dichev (1997) posits that avoidance of a loss increases firm value, we expect a firm is more likely to exclude stock-based compensation expense from pro forma earnings when a firm reports positive earnings only if stock-based compensation expense is excluded. $\sigma(C O M P X A)$ is the standard deviation of a firm's COMPXA across sample years. ${ }^{13}$ We expect that managers' desire for smoother earnings leads to a higher likelihood of exclusion when the volatility of a firm's stockbased compensation expense is greater and, thus, expect a positive relation between $\sigma(C O M P X A)$ and exclusion of the expense. ${ }^{14,15}$

Our incentive variables relate not only to managers, but also to analysts. Prior research suggests analysts have incentives to exclude an expense from Street earnings when managers have incentives to exclude it from pro forma earnings because, for example, analysts desire to curry favor with the firm to obtain investment banking business (Francis and Philbrick, 1993; Lin and McNichols, 1998; Michaely and Womack, 1999; Richardson, Teoh, and Wysocki, 2004). Managers also may influence analysts' exclusions through earnings guidance (Christensen et al., 2011). Thus, managers' incentives can also explain exclusions from Street earnings. We also expect analysts to have their own incentives to avoid earnings surprises,

\footnotetext{
${ }^{13}$ Untabulated tests reveal that our inferences are unaffected if we use the variability of net income minus stockbased compensation expense instead of $\sigma(C O M P X A)$.

${ }^{14}$ This is consistent with the statement by TIBCO Software Inc. in its December 21, 2006 8-K, explaining its exclusion of stock-based compensation from pro forma earnings: "the nature of the stock-based compensation expense also makes it very difficult to estimate prospectively, since the expense will vary with changes in the stock price and market conditions at the time of new grants, varying valuation methodologies, subjective assumptions and different award types."

${ }^{15}$ These variables also could identify situations in which investors would like more information about stock-based compensation expense and managers oblige. However, firms could provide such information without using pro forma earnings, as regulated by Reg G, that excludes stock-based compensation expense, which is how we define EX_PROFORMA. See footnote 26.
} 
relative to their forecasts, and having to predict a difficult-to-predict earnings component, i.e., one with greater variance (Lambert, 2004). Even though our incentive variables relate to managers and analysts, how the incentives relate to managers' and analysts' exclusion of stockbased compensation expense likely differs. Estimating equation (1) separately for the two types of exclusions permits the relations to differ.

The next three variables in equation (1) are proxies for information asymmetry. We include them because it is possible that information asymmetry affects incentives of both managers and analysts to exclude stock-based compensation expense. Based on prior literature, the proxies are: $\sigma(A F)$, the standard deviation of a firm's analyst forecasts of earnings deflated by total assets, measured one year prior to fiscal year-end; ANALYSTS, the number of analysts providing earnings forecasts for the firm; and INSTIT, the percentage of shares outstanding held by institutional investors as reported on Form 13-F.

We also include in equation (1) POLICY, which is an indicator variable that equals one if the firm is covered by at least one of seven large brokerage firms that the popular press reports require their analysts to include stock-based compensation expense in their earnings forecasts, and zero otherwise. ${ }^{16}$ We expect that firms covered by these brokerage firms are less likely to have the expense excluded. We also include in equation (1) ROA and SIZE as control variables, where $R O A$ is the ratio of actual earnings as reported by $\mathrm{I} / \mathrm{B} / \mathrm{E} / \mathrm{S}$ to beginning of year total assets and SIZE is the natural logarithm of end of year market value of equity, as well as industry fixed effects. $^{17}$

\footnotetext{
${ }^{16}$ These firms are Bank of America, Bear Stearns, Credit Suisse First Boston, Goldman Sachs, Merrill Lynch, Sanford C. Bernstein, and UBS. See, e.g. Taub, S. "Staggered start for options expensing." CFO.com. June 1, 2005 and "Stock options: So who's counting," New York Times, nytimes.com, August 6, 2005. Our inferences are unaffected if POLICY equals one if a majority of the brokers following the firm have a policy to include the expense, or if we eliminate firms for which a majority of brokers following the firm have such a policy.

${ }^{17}$ Our inferences are unaffected if we define SIZE as the natural logarithm of total assets.
} 


\subsection{Predictive ability}

We conduct two sets of tests of the predictive ability explanation for exclusion of stockbased compensation expense from pro forma or Street earnings. In the first set, we focus on differences in the predictive ability for future earnings of earnings measures that exclude and include the expense, and whether those differences support the exclusion or inclusion decisions by managers and analysts. ${ }^{18}$ In particular, we compare the explanatory powers from equations (2) and (3) for Pro Forma Excluders and Includers and for Street Excluders and Includers.

$$
\begin{gathered}
\operatorname{EARN}_{t+1}=\alpha_{0}+\alpha_{1} \operatorname{EARN}_{t}+\alpha_{2} \operatorname{SIZE}_{t}+\alpha_{3} B M_{t}+\varepsilon_{t} \\
\operatorname{EARN}_{t+1}=\alpha_{0}+\alpha_{1}\left(\operatorname{EARN}_{t}-\operatorname{COMPXA}_{t}\right)+\alpha_{2} \operatorname{SIZE}_{t}+\alpha_{3} B M_{t}+\varepsilon_{t}
\end{gathered}
$$

$E A R N$ is net income before extraordinary items deflated by beginning of year total assets, and $t$ denotes year. $B M$ is the end of year equity book to market ratio.

Equation (2) does not include stock-based compensation expense as a potential predictor of future earnings, but equation (3) does. Because we do not expect the predictive ability of stock-based compensation expense to explain exclusion of the expense from pro forma earnings, we expect that equation (2) ((3)) has no greater explanatory power for Pro Forma Excluders (Includers) than does equation (3) ((2)). ${ }^{19}$ In contrast, because we expect the predictive ability of stock-based compensation expense to explain exclusion of the expense from Street earnings, we expect that equation (2) has more (less) explanatory power than equation (3) for Street Excluders (Includers).

An important feature of our research design is that in all of our predictive ability tests the

\footnotetext{
${ }^{18}$ We test for differences in predictive ability for future earnings. However, untabulated findings from tests for differences in predictive ability for future cash from operations reveal the same inferences.

${ }^{19}$ Our tests of significance are based on a non-parametric goodness of fit test because Clarke (2003, 2007) shows the test is superior to the Vuong (1989) test when the sets of explanatory variables are highly correlated, as they are in our setting.
} 
latest year of data we use is 2005 , i.e., the relations we estimate predate the effective date of SFAS 123R. This feature ensures that none of the variables in equations (2) through (5) reflects stock-based compensation expense, thereby ruling out the possibility of a mechanical relation between the variables that is attributable to recognized stock-based compensation expense. ${ }^{20}$ This research design feature also ensures that our inferences are not confounded by the possibility that the predictive ability of the expense, or a firm's use of stock-based compensation post SFAS 123R, is caused by exclusion. We include year and industry fixed effects in equations (2) through (5) and calculate $t$-statistics using standard errors clustered by firm and by year (Gow, Ormazabal, and Taylor, 2010). ${ }^{21}$

Our second set of tests relating to the predictive ability explanation focuses on differences in predictive ability of stock-based compensation expense for future earnings. Our tests are adapted from prior research that tests for differences in the predictive abilities of GAAP earnings and exclusions (e.g., Doyle, Lundholm, and Soliman, 2003). In particular, we estimate equation (4).

$$
\begin{aligned}
& E A R N_{t+1}=\alpha_{0}+\alpha_{1} E A R N_{t}+\alpha_{2} C O M P X A_{t}+\varphi_{0} E X+\varphi_{1} E X^{*} C O M P X A_{t} \\
& +\alpha_{3} S I Z E_{t}+\alpha_{4} B M_{t}+\varepsilon_{t}
\end{aligned}
$$

We expect that for Street Excluders stock-based compensation expense has less predictive ability for future earnings than for Street Includers. Thus, for $E X=E X \_S T R E E T$, we expect $\varphi_{1}$ differs significantly from zero in a way that evidences less predictive ability of COMPXA than does $\alpha_{2}$,

\footnotetext{
${ }^{20}$ For example, in equation (2) if earnings, $E A R N$, were based on net income that included stock-based compensation expense, we could find a significant negative relation between $E A R N_{t+1}$ and $C O M P X A_{t}$ solely because higher expense is associated with lower net income. By basing $E A R N$ on net income prior to the recognition of stock-based compensation expense, we rule out this possibility.

${ }^{21}$ When estimating all of our equations, we eliminate outliers. Following Belsley, Kuh, and Welsch (1980) we classify outliers as those observations with studentized residuals greater than three in absolute value. All inferences are unaffected by the inclusion of outliers.
} 
or even that $\alpha_{2}+\varphi_{1}$ is not significantly different from zero. We do not expect the predictive ability of stock-based compensation expense to differ for Pro Forma Excluders and Pro Forma Includers. Thus, for $E X=E X \_P R O F O R M A$, we expect $\varphi_{1}$ is not significantly different from zero.

To allow for the possibility that time-invariant cross-sectional differences between firms whose consensus forecasts exclude and include stock-based compensation expense, i.e., correlated omitted variables, confound our inferences, we also estimate a version of equation (4) using changes in earnings (Christie, 1987; Kothari and Zimmerman, 1995). In particular, we estimate equation (5).

$$
\begin{aligned}
\triangle E A R N_{t+1}= & \alpha_{0}+\alpha_{1} \Delta E A R N_{t}+\alpha_{2} \Delta C O M P X A_{t}+\varphi_{0} E X+\varphi_{1} E X^{*} \Delta C O M P X A_{t} \\
& +\alpha_{3} \operatorname{SIZE}_{t}+\alpha_{4} B M_{t}+\varepsilon_{t}
\end{aligned}
$$

where $\Delta$ denotes annual change. ${ }^{22}$ As with equation (4), when $E X=E X \_S T R E E T$, we expect $\varphi_{1}$ differs significantly from zero in a way that evidences less predictive ability of $\triangle C O M P X A$ than does $\alpha_{2}$, or even that $\alpha_{2}+\varphi_{1}$ is not significantly different from zero; when $E X=$ EX_PROFORMA, we expect $\varphi_{1}$ is not significantly different from zero.

To the extent that analysts exclude stock-based compensation expense for reasons other than differences in predictive ability, our ability to detect differences for Street Includers and Street Excluders in equations (2) through (5) will be diminished. For example, if analysts exclude the expense because they are currying favor with managers or are following managers' lead and managers' exclusions are unrelated to predictive ability, then the power of our tests to find that predictive ability explains Street exclusion will be lower.

\footnotetext{
${ }^{22}$ We also estimated equations (4) and (5) including $E X^{*} E A R N_{t}$ and $E X^{*} \Delta E A R N_{t}$, respectively, with no change in our inferences.
} 


\section{Sample, Data, and Descriptive Statistics}

To construct our sample, we first identify Street Excluders as those firms Bear Stearns U.S. Equity Research lists as having stock-based compensation expense excluded from their consensus analyst forecast of 2006 earnings (Senyek et al., 2007). Bear Stearns considered firms in the S\&P 500 and the NASDAQ 100, as well as other firms with a large difference between earnings as determined by GAAP and as reported by First Call. For these firms, Bear Stearns reviewed the First Call footnotes or notation for whether the consensus earnings forecast included or excluded stock-based compensation expense. As an additional check, Bear Stearns reviewed press releases and company filings to verify the difference between GAAP earnings and earnings as reported by First Call. Bear Stearns lists 102 firms whose consensus forecast of 2006 earnings excludes stock-based compensation expense-38 from the S\&P 500, 32 from the NASDAQ 100, and 55 firms in neither index; 98 of these meet our data requirements. ${ }^{23}$ We then identify Street Includers as firms that are in the same industry as at least one Street Excluder, using the Barth, Beaver, and Landsman (1998) industry definitions.

To be included in our sample, we require firms to have data necessary to estimate equation (1) and at least one year of data to estimate equations (2) through (5). Thus, sample firms must have (i) non-negative 2005 stock-based compensation expense, COMPX; (ii) a consensus forecast of 2005 earnings, which is the latest consensus forecast prior to the end of the

\footnotetext{
${ }^{23}$ Some related research (e.g., Gu and Chen, 2004; Baik, Farber, and Petroni, 2009) uses the First Call footnote file to determine whether analyst forecasts exclude an earnings component. We use the Bear Stearns list because of the additional analysis performed by Bear Stearns to verify whether the First Call footnotes were correct with respect to the exclusion of stock-based compensation expense. Also, we identified three types of errors in the footnote file. First, not all firms have footnotes indicating whether stock-based compensation expense is included in or excluded from the forecast. For example, there is no footnote related to stock-based compensation expense for Google's 2006 earnings forecast, but we confirmed that stock-based compensation expense is excluded from the forecast as the Bear Stearns list indicates. Second, some firms have multiple footnotes that conflict as to whether the forecast includes or excludes the expense. Third, some firms have a footnote indicating exclusion, but we confirmed from press releases and analyst reports that the forecasts include the expense, consistent with the Bear Stearns analysis. See Baik, Farber, and Petroni (2009) for other caveats regarding use of the First Call footnote file.
} 
firm's fiscal year 2005 on the I/B/E/S summary file; (iii) at least one observation of stock-based compensation expense for a year prior to 2005 , to calculate $\sigma(C O M P X A)$; (iv) institutional holdings data from Thompson Financial; and (iv) non-missing 2005 market value of equity, total assets, net income before extraordinary items, number of shares outstanding, and book value of equity. We obtain accounting data from Compustat, market value of equity from CRSP, and analyst earnings forecasts from $\mathrm{I} / \mathrm{B} / \mathrm{E} / \mathrm{S}$. Because early adoption of the grant date value measurement approach in SFAS 123 may confound our inferences, we eliminate firms that voluntary recognize stock-based compensation expense (McConnell et al., 2003). ${ }^{24}$ The resulting sample comprises 1,845 firms that meet our data requirements, 98 Street Excluders and 1,747 Street Includers.

To determine which of our 1,845 sample firms are Pro Forma Excluders and Pro Forma Includers, we hand-collected earnings announcements for fiscal 2006 for each firm from the SEC's website. We inspected earnings announcements that include the words "non-GAAP" or "pro forma" to identify firms that disclosed a measure of non-GAAP earnings or earnings per share that is reconciled to GAAP earnings or earnings per share, as required by the SEC, and the reconciliation shows that the non-GAAP measure excludes stock-based compensation expense. ${ }^{25}$ If the firm discloses a non-GAAP measure for fiscal 2006 that (i) excludes stock-based compensation expense and (ii) is reconciled with net income (or a net income-derived measure, such as earnings per share), we code it as a Pro Forma Excluder (344 firms), otherwise we code

\footnotetext{
${ }^{24}$ These eliminations were of potential Street Includers; no Street Excluder voluntarily recognized the expense. ${ }^{25}$ SEC Staff Accounting Bulletin No. 107 requires firms that disclose a non-GAAP earnings measure to label the measure as non-GAAP and reconcile the non-GAAP measure to the most comparable GAAP measure, namely earnings or earnings per share. Some firms disclose other earnings-based measures typically labeled "adjusted EBITDA" or something similar. We do not label these firms as Pro Forma Excluders unless the firm also excludes stock-based compensation expense from a non-GAAP measure of earnings or earnings per share that is reconciled to GAAP earnings or earnings per share
} 
it as a Pro Forma Includer (1,501 firms). ${ }^{26}$

Our opportunism tests use data only from 2005 and, thus, are based on 1,845

observations. Our predictive ability tests use data from 1998 to 2005 . Our sample period begins in 1998 because stock-based compensation expense is available beginning in 1996 and equation (5) requires lagged change in stock-based compensation expense. Thus, for our predictive ability tests, we use 8,406 firm-year observations, $601(1,742)$ of which are Street (Pro Forma) Excluders and 7,805 $(6,664)$ of which are Street (Pro Forma) Includers.

Table 1 presents descriptive statistics for our sample and data. Panel A presents the distribution of our 1,845 sample firms by Street and Pro Forma Includer and Excluder classifications. Panel A reveals that firms and analysts differ in their exclusion of stock-based compensation expense for 256 firms - 251 of the 344 Pro Forma Excluders are Street Includers, and 5 of the 98 Street Excluders are Pro Forma Includers. ${ }^{27}$ These differences between firms and analysts suggest that different factors explain exclusion of the expense from pro forma and Street earnings. Table 1, panel B, presents the industry composition of the sample. Of seven industries in our sample, the largest numbers of excluders are in the Computers industry, 170 of 344 Pro Forma Excluders and 70 of 98 Street Excluders. ${ }^{28}$

Table 1, panel C, presents descriptive statistics for the 2005 amounts relating to variables used in our tests, separately for Pro Forma Excluders and Includers. The $t$-statistics (Wilcoxon

\footnotetext{
${ }^{26}$ Street and Pro Forma Includers could include firms with exclusions of other, possibly recurring, earnings components. To the extent that the incentives for stock-based compensation expense exclusion are the same as for exclusion of other earnings components our tests will be biased against finding support for the opportunism explanation. However, exclusions of other earnings components will not affect our predictive ability tests because those tests focus only on the predictive ability of stock-based compensation expense.

${ }^{27}$ Bhattacharya et al. (2003) reports that Street and pro forma earnings differ about one-third of the time and, thus, our proportion of $14 \%(256 / 1,845)$ might appear low. However, our sample includes firms that did not have exclusions from either Street or pro forma earnings, which appear as firms for which analysts and managers agree, whereas the Bhattacharya et al. (2003) sample includes only firms with exclusions of one or the other type.

${ }^{28}$ In section 6.3 we estimate equations (1), (4), and (5) separately for computer and non-computer firms.
} 
Z-statistics) test for differences in means (ranks) of the variables between the two groups of firms. Panel B reveals significant differences for Pro Forma Excluders and Includers, except for the median of dispersion of analyst forecasts, $\sigma(A F)$. For example, the panel reveals that Pro Forma Excluders have significantly higher earnings, EARN; the means (medians) for Pro Forma Excluders and Pro Forma Includers are 0.05 and -0.03 (0.07 and 0.05) and the $t$-statistic (Zstatistic) is 4.06 (6.05). The panel also reveals that Pro Forma Excluders are larger, SIZE, have lower book-to-market ratios, $B M$, and have more stock-based compensation expense, COMPXA. They also have significantly higher unexpected earnings, IPOSSURP; more frequently would have reported a loss if stock-based compensation expense were included in net income, ILOSS; have more variable stock-based compensation expense, $\sigma(C O M P X)$; have less dispersion in analyst forecasts, $\sigma(A F)$; have more institutional investors, INSTIT; have greater analyst coverage, ANALYSTS; and are less likely to be covered by one of the seven brokerage firms that had a policy of including stock-based compensation expense in analyst forecasts, POLICY. Panel D presents analogous statistics for Street Excluders and Includers, and reveals differences in means and medians similar to those in panel C.

Table 1, panel E, presents correlations between the variables and untabulated statistics indicate that many of the correlations are significantly different from zero. Panel E reveals that the signs of the correlations between EX_STREET and EX_PROFORMA and the other variables we use in our analyses are the same. However, it also reveals that the correlation between EX_STREET and EX_PROFORMA is 0.46 . Thus, exclusions of stock-based compensation expense by analysts and managers are positively, but not perfectly correlated. We base our inferences on the multivariate relations specified in equations (1) through (5). 


\section{Results}

\subsection{Opportunism}

Table 2 presents summary statistics from estimating four versions of equation (1). The first (third) version focuses on explaining exclusion of stock-based compensation expense from pro forma (Street) earnings and, thus, EX_PROFORMA (EX_STREET) is the dependent variable. The second (fourth) version differs from the first (third) in that it also includes EX_STREET (EX_PROFORMA) as an explanatory variable to permit us to test whether the incentives explain exclusions from pro forma (Street) earnings incremental to their association with exclusion from Street (pro forma) earnings.

Regarding exclusion from pro forma earnings, consistent with the opportunism explanation, the first set of columns reveals that the likelihood of excluding stock-based compensation expense is significantly higher for firms with a larger expense (COMPXA $t$-stat. $=$ 3.54), for firms that beat analyst expectations in the prior year, (IPOSSURP $t$-stat. $=2.75)$, when including stock-based compensation expense in the prior year would have caused an otherwise profitable firm to report a loss, although not significantly so (ILOSS $t$-stat. $=1.23)$, and for firms with greater historical volatility of stock-based compensation expense $(\sigma(C O M P X A) t$-stat. $=$ 3.41).

The first set of columns also reveals that exclusion is significantly more likely when more analysts follow the firm $($ ANALYSTS $t$-stat. $=5.64)$ and the firm has greater institutional ownership (INSTIT $t$-stat. $=2.02)$. There is no significant relation between pro forma exclusion of the expense and analyst forecast dispersion and whether a firm is covered by one of the seven large brokerage houses that have a policy of their analysts including stock-based compensation expense in their forecasts $(\sigma(A F) t$-stat. $=0.00 ;$ POLICY $t$-stat. $=-0.17)$. Regarding the control 
variables, the first set of columns reveals that firms with higher return on assets and smaller firms are more likely to exclude the expense (ROA $t$-stat. $=4.19 ;$ SIZE $t$-stat. $=-2.28)$.

The second set of columns reveals that exclusion of the expense from Street earnings is significantly associated with its exclusion from pro-forma earnings. This is consistent with the statistics in table 1, panel A, which reveal that Street and pro forma earnings exclusions are the same (differ) for 1,589 (256) sample firms. The coefficient on EX_STREET is significantly positive $(t$-stat. $=11.37)$. The columns also reveal inferences relating to the opportunism incentive variables that are identical to those revealed by the first set of columns. In particular, the coefficients on COMPXA, IPOSSURP, and $\sigma(C O M P X)$ are significantly positive $(t$-stats. $=$ 3.42, 2.11, and 3.22), and that on ILOSS is not significantly different from zero $(t$-stat. $=0.65)$. These findings indicate that the opportunism incentive variables explain exclusions from pro forma earnings when they differ from exclusions from Street earnings. The second set of columns also reveals inferences relating to the other variables, $\sigma(A F)$ ANALYSTS, INSTIT, POLICY, ROA, and SIZE, that are identical to those revealed by the first set of columns. Regarding exclusion of stock-based compensation expense from Street earnings, the third set of columns in table 2 reveals that several variables that explain exclusion from pro forma earnings also explain exclusion from Street earnings. The differences are that analyst forecast dispersion is significantly negatively associated with Street earnings exclusion $(\sigma(A F) t$-stat. $=-$ 2.08), which indicates that exclusion of stock-based compensation expense from the consensus forecast is associated with greater disagreement among individual analysts than inclusion of the expense. Institutional ownership and firm size are not significantly associated with exclusion from Street earnings (INSTIT $t$-stat. $=0.74 ;$ SIZE $t$-stat. $=0.56)$. These findings are consistent with analysts either responding to their own opportunism incentives or catering to managers' 
opportunism.

As in the second set of columns, the statistics in the fourth set of columns reveal that exclusion of the expense from pro forma earnings is significantly associated with its exclusion from Street earnings. The coefficient on EX_PROFORMA is significantly positive $(t$-stat. $=$ 8.77). More importantly, and in contrast to the findings in the second set of columns, the fourth set of columns reveals that the incentives have little power in explaining the 256 Street exclusions that differ from pro forma exclusions. ${ }^{29}$ In particular, when EX_PROFORMA is included as an explanatory variable, the coefficients on $C O M P X A$ and $\sigma(C O M P X)$ are not significantly different from zero ( $t$-stats. $=0.75$ and 0.53 ), whereas they are significantly positive in the third set of columns ( $t$-stats. $=3.55$ and 1.96). The only incentive that has a significant relation with Street exclusion after controlling for pro forma exclusion is $\operatorname{IPOSSURP}(t$-stat. $=$ 1.91). The only other differences between the findings in the third and fourth sets of columns are that in the fourth set the coefficient on $R O A$ is not significantly different from zero ( $t$-stat. = $1.00)$ and that on SIZE is significantly positive $(t$-stat. $=2.82)$.

Taken together, the findings in table 2 suggest that opportunism explains firms' exclusion of stock-based compensation expense from pro forma earnings, and that opportunism largely does not explain Street exclusion after controlling for pro forma exclusion.

\subsection{Predictive ability}

Table 3 presents summary statistics from estimating equations (2) and (3). Panel A presents statistics for Pro Forma Includers and Excluders, and panel B presents statistics for Street Includers and Excluders. Recall that the statistics in table 3 are based on data before 2006 and, thus, the predictive ability of stock-based compensation expense revealed in table 3 was

\footnotetext{
${ }^{29}$ Our inferences are unaffected if we eliminate the five Street Excluders that are Pro Forma Includers.
} 
available to firms and analysts when deciding whether to include or exclude the expense from 2006 pro forma and Street earnings.

Turning first to panel $\mathrm{A}$, the statistics indicate that excluding stock-based compensation expense from earnings of Pro Forma Excluders does not increase the predictive ability of current earnings, $E A R N$, for future earnings. In fact, the panel reveals that exclusion of stock-based compensation expense by Pro Forma Excluders reduces the predictive ability of current $E A R N$ for future EARN. That is, Model 2 has significantly greater explanatory power than Model 1 ( $p$ value $<0.01)$. The panel also reveals that inclusion of the expense by Pro Forma Includers reduces the predictive ability of current $E A R N$ for future $E A R N$ in that for those firms, Model 1 has significantly greater explanatory power than Model 2. These findings are not consistent with firms including or excluding stock-based compensation expense from pro forma earnings to increase the predictive ability of earnings. In fact, the findings indicate firms exclude stockbased compensation expense from pro forma earnings when including it would result in earnings with greater predictive ability for future performance, not less.

Panel B reveals the opposite inference for Street Excluders and Includers. In particular, the statistics in panel B are consistent with the predictive ability explanation, in that Model 1 has greater explanatory power for Street Excluders and Model 2 has greater explanatory power for Street Includers. Excluding stock-based compensation expense from earnings significantly increases the adjusted $\mathrm{R}^{2}$ for Street Excluders (from $35.25 \%$ to $36.23 \%$; $p$-value $<0.01$ ), and including the expense significantly increases the adjusted $\mathrm{R}^{2}$ for Street Includers (from $42.77 \%$ to $43.63 \%$; $p$-value $<0.01)$. These findings indicate that the treatment of stock-based compensation expense by analysts in the consensus earnings forecast increases the predictive ability of current earnings for future performance. As a benchmark against which to gauge the 
economic significance of these differences in $\mathrm{R}^{2}$, we estimate our equations replacing stockbased compensation expense with other expenses commonly excluded from other non-GAAP earnings measures, such as EBITDA, namely interest, tax, and depreciation expense. In untabulated analyses, we find that similar or smaller differences in $\mathrm{R}^{2}$ result from inclusion of these earnings components, $0.66,0.22$, and -0.07 percentage points respectively. ${ }^{30}$

Table 4 presents summary statistics from estimating equation (4), in panel A, and equation (5), in panel B. The first column in panel A reveals that when we constrain the coefficient on stock-based compensation expense to be the same for all firms, the coefficient on $E A R N_{t}$ is significantly positive $(t$-stat. $=15.22)$, indicating, as expected, that current $E A R N$ is a significant predictor of future $E A R N$. The first column also reveals that the coefficient on COMPXA is significantly negative $(t$-stat. $=-2.30)$, which indicates that, on average, stock-based compensation expense is a significant predictor of future $E A R N$ — the larger is current stockbased compensation expense, the smaller is future $E A R N$. In addition, the coefficient on SIZE is significantly positive $(t$-stat. $=2.29)$ and that on $B M$ is significantly negative $(t$-stat. $=-6.04)$.

The second column in panel A presents summary statistics from equation (4) when we permit the coefficient on $C O M P X A$ to vary for Pro Forma Excluders, i.e., with $E X=$ EX_PROFORMA. The second column reveals the same inferences for SIZE, BM, and $E A R N_{t}$, as the first column. More importantly for our research question, the second column reveals that the coefficients on $C O M P X A$ are significantly negative for Pro Forma Includers and Pro Forma Excluders (coef. $=-0.37, t$-stat. $=-4.08$ for Includers; coef. $=-0.14, p$-value $<0.01$ for

\footnotetext{
${ }^{30}$ In both panels, the $\mathrm{R}^{2} \mathrm{~S}$ of both Model 1 and Model 2 are higher for Includers than for Excluders. The $\mathrm{R}^{2} \mathrm{~s}$ in panel A for Pro Forma Includers (Excluders) are $46.88 \%$ and $45.61 \%$ (28.64\% and 30.16\%), and in panel B for Street Includers (Excluders) are $42.77 \%$ and $43.63 \%$ (36.23\% and 35.25\%). The smaller $\mathrm{R}^{2} \mathrm{~s}$ for Excluders is consistent with Excluders having more transitory earnings components than Includers. However, differences in $\mathrm{R}^{2} \mathrm{~s}$ between Includers and Excluders do not affect our inferences, which are based on the difference in $\mathrm{R}^{2} \mathrm{~s}$ for Model 1 and Model 2 within each Includer and Excluder group, not between the groups. The only difference between Model 1 and Model 2 is whether stock-based compensation expense is included in the explanatory earnings variable.
} 
Excluders), and that the difference between the two coefficients is not significantly different from zero $\left(E X^{*} C O M P X A\right.$ coef. $=0.23, t$-stat. $\left.=1.38\right)$. These findings do not support the predictive ability explanation for pro forma earnings. That is, as in table 3, table 4, panel A, provides no evidence that firms exclude stock-based compensation expense from pro forma earnings to create an earnings measure with greater predictive ability for future performance.

As in table 3, the third column of panel A reveals the opposite inferences for Street earnings. In particular, the third column reveals that stock-based compensation expense has predictive ability for future $E A R N$ for Street Includers (coef. $=-0.22, t$-stat. $=-2.60$ ), and the same is not true for Street Excluders. The coefficient on $E X^{*} C O M P X A$ of $0.23(t$-stat. $=2.28)$ results in a total coefficient on COMPXA for Street Excluders of $0.01\left(\alpha_{2}+\varphi_{1}=-0.22+0.23\right)$, which is not significantly different from zero $(p$-value $=0.78)$. These findings support the predictive ability explanation for Street earnings. That is, as in table 3, table 4, panel A, provides evidence that analysts exclude stock-based compensation expense from Street earnings to create an earnings measure with greater predictive ability for future performance.

Table 4, panel B, presents summary statistics from equation (5) that are analogous to those in panel A from equation (4), and reveal similar inferences. In particular, the first column of panel B reveals that when we constrain the coefficient on $\triangle C O M P X A$ to be the same for Pro Forma Includers and Excluders, $\triangle C O M P X A$ has predictive ability for future $\triangle E A R N(t$-stat. $=-$ 3.88). In addition, the second column reveals that exclusion of stock-based compensation expense from pro forma earnings is not associated with differences in predictive ability. The coefficients on COMPXA are significantly negative for Pro Forma Includers and Pro Forma Excluders (coef. $=-0.73, t$-stat. $=-5.38$ for Pro Forma Includers; coef. $=-0.14, p$-value $<0.01$ for Pro Forma Excluders), and the difference between the coefficients is not significantly 
different from zero (coef. on $E X^{*} \triangle C O M P X A=0.59, t$-stat. $=1.47$ ). In contrast, as in panel A, the third column reveals that changes in stock-based compensation expense have predictive ability for future changes in $E A R N$ for Street Includers (coef. $=-0.47, t$-stat. $=-4.54$ ), and the same is not true for Street Excluders. The significant positive coefficient on $E X^{*} C O M P X A$ (coef. $=0.45, t$-stat. $=2.99)$ indicates that, for Street Excluders, the total effect of COMPXA is $0.02\left(\alpha_{2}+\varphi_{1}=-0.47+0.45\right)$ which is not significantly different from zero $(p$-value $=0.60)$.

Taken together, the findings in table 4 support the predictive ability explanation for exclusion of stock-based compensation expense from Street earnings, but not from pro forma earnings. The findings indicate that the expense has predictive ability for future earnings for Pro Forma Excluders as well as Pro Forma Includers. In contrast, not only does stock-based compensation expense have less predictive ability for future earnings for Street Excluders than for Street Includers, but also the expense has no significant predictive ability for future earnings for Street Excluders yet has significant predictive ability for Street Includers.

\subsection{Additional analyses}

\subsubsection{Decomposition of exclusion from Street earnings}

To the extent opportunism is associated with the predictive ability of stock-based compensation expense, our inferences regarding either explanation may be confounded. To investigate this possibility, we decompose the indicator variable for exclusion from Street earnings, $E X=E X \_S T R E E T$, into the predicted value, $E X \_P R E D$, and the residual, $E X \_R E S$, based on estimated coefficients from equation (1) and estimate the following modified versions of equations (4) and (5).

$$
\begin{aligned}
E_{A R N_{t+1}=\alpha_{0}+} & \alpha_{1} E A R N_{t}+\alpha_{2} C O M P X A_{t}+\varphi_{0} E X \_P R E D+\varphi_{1} E X \_P R E D^{*} C O M P X A_{t} \\
& +\varphi_{2} E X \_R E S+\varphi_{3} E X \_R E S^{*} C O M P X A_{t}+\alpha_{3} S I Z E_{t}+\alpha_{4} B M_{t}+\varepsilon_{t}
\end{aligned}
$$




$$
\begin{aligned}
\triangle E A R N_{t+1}=\alpha_{0}+ & \alpha_{1} \Delta E A R N_{t}+\alpha_{2} \Delta C O M P X A_{t}+\varphi_{0} E X \_P R E D+\varphi_{1} E X \_P R E D^{*} \triangle C O M P X A_{t} \\
& +\varphi_{2} E X \_R E S+\varphi_{3} E X \_R E S^{*} \Delta C O M P X A_{t}+\alpha_{3} S I Z E_{t}+\alpha_{4} B M_{t}+\varepsilon_{t}
\end{aligned}
$$

If the variables in equation (1) do (do not) explain the differences in predictive ability of stockbased compensation expense for future earnings between Street Includers and Street Excluders evident in table 4 , then we expect the table 4 differences to be attributable to the predicted (residual) component of $E X$. Thus, if opportunism does (does not) explain the differences in predictive ability, we expect $\left(\varphi_{1}\right) \varphi_{3}$ differs significantly from zero in a way that evidences less predictive ability for $C O M P X A$ or $\triangle C O M P X A$.

Table 5 presents summary statistics from estimating equation (6), in the first column, and equation (7), in the second column. Consistent with table 4, table 5 reveals that the coefficients on COMPXA and $\triangle C O M P X A$ are significantly negative ( $t$-stats. $=-2.31$ and -3.56$)$. More importantly for our research question, the coefficients on $E X \_R E S^{*} C O M P X A$ and $E X \_R E S^{*} \triangle C O M P X A$ are both significantly positive $(t$-stats. $=2.85$ and 2.31$)$, and the coefficients on $E X \_P R E D^{*} C O M P X A$ and $E X \_P R E D^{*} \triangle C O M P X A$ are not significantly different from zero $(t$-stats. $=0.56$ and 0.36$)$. These findings indicate that differences in the predictive ability of stock-based compensation expense between Street Excluders and Street Includers are not associated with the variables in equation (1), which supports the inference that analysts exclude the expense from Street earnings to obtain an earnings number with greater predictive ability for firm performance.

\subsubsection{Computer firms and non-computer firms}

High technology firms were among the most vocal opponents to recognizing stock-based compensation expense and table 1, panel $\mathrm{B}$, reveals that computer firms comprise a large portion of the sample. Thus, we investigate whether our findings apply to both computer and non- 
computer firms by estimating our equations separately for the two groups of firms. The results should be viewed with caution, given the smaller number of observations underlying these estimations than in our primary tests.

Table 6, panel A, presents summary statistics from equation (1) estimated separately for computer and non-computer firms and, in the case of $E X=E X \_S T R E E T$, modified to include EX_PROFORMA as an explanatory variable. The first two columns of panel A, relating to exclusions from pro forma earnings, i.e., $E X=E X \_P R O F O R M A$, reveal that the regression explanatory power is approximately the same for firms in both industry groups $\left(\mathrm{McFadden} \mathrm{R}^{2}=\right.$ 9.48\% for Computer firms and 6.24\% for Non-Computer firms), although different variables are significant in explaining exclusion for the two types of firms. In particular, the coefficients on IPOSSURP and $\sigma(C O M P X)$ are significantly different from zero for Computer firms, but not Non-Computer firms, and the coefficients on COMPXA and ILOSS are significantly different from zero for Non-Computer firms, but not Computer firms. The coefficients on ANALYSTS and INSTIT are significantly different from zero for both Computer and Non-Computer firms.

The second two columns relating to exclusions from Street earnings, i.e., when $E X=$ EX_STREET, also reveal that the regression explanatory power is approximately the same for firms in both industry groups (McFadden $\mathrm{R}^{2}=49.18 \%$ for Computer firms and $54.99 \%$ for NonComputer firms), and that, as with pro forma exclusions, different variables are significant in explaining Street earnings exclusion for firms in the two industry groups. For example, the coefficients on EX_PROFORMA and SIZE are significantly different from zero for both groups of firms, but those on $\sigma(C O M P X)$ and ANALYSTS are significantly different only for NonComputer firms. One explanation for the results in panel A is that the strengths of the various 
incentives vary by industry, for example, avoiding losses may be more important for noncomputer firms.

Table 6, panel B, presents summary statistics from estimating equation (4) for $E X=$ EX_PROFORMA (EX $\left.=E X \_S T R E E T\right)$ for Computer and Non-Computer firms in the first (second) set of columns. The results for $E X=E X \_P R O F O R M A$ reveal the same inferences for firms in both industry groups as does table 5. In particular, for Pro Forma Excluders and Includers, stock-based compensation expense has predictive ability for future earnings. The total coefficients on COMPXA for Pro Forma Includers and Excluders are significantly negative (for Computer Pro Forma Includers and Excluders, coef. $=-0.52, t$-stat. $=-2.37$ and coef. $=-0.15, p$ value $<0.01$; for Non-Computer Pro Forma Includers and Excluders, coef. $=-0.42, t$-stat. $=-2.73$ and coef. $=-0.56, p$-value $<0.01)$.

The results for $E X=E X \_S T R E E T$ in the second set of columns also reveal the same inferences as does table 5. The coefficient on COMPXA is significantly negative for Computer and Non-Computer Street Includers (coefs. $=-0.37$ and $-0.57 ; t$-stats. $=-2.38$ and -3.42 ), and not significantly different from zero for Computer and Non-Computer Street Excluders (coefs. = -0.08 and $0.31 ; p$-values $=0.28$ and 0.30 ). In addition, the difference in the coefficients is significantly positive for firms in both industry groups $(t$-stats. $=2.43$ and 3.99 for Computer and Non-Computer firms). These results indicate that regardless of whether the firm is in the computer industry, analysts exclude stock-based compensation expense when it has no predictive ability for firm performance, but increasing the predictive ability of earnings does not explain exclusion of the expense from pro forma earnings by managers. 


\subsubsection{First Call footnote file data}

As explained in Section 5, we use the Bear Stearns U.S. Equity Research list of excluders to identify Street Excluders instead of the First Call footnote file because we believe it more reliably identifies these firms. Nonetheless, in this section we use the footnote file data to provide a validity check on our analyses.

The footnote file indicates that the consensus forecasts of 2006 earnings for 268 firms (75 Street Excluders and 193 Street Includers) exclude stock-based compensation expense. Consistent with errors in the footnote file (see footnote 23), untabulated statistics reveal that the mean of an indicator variable that equals one if the firm's 2006 consensus earnings forecast has a footnote in the file indicating that stock-based compensation expense is excluded from the forecast, and zero otherwise, is 0.77 for Street Excluders and 0.11 for Street Includers. If the footnote file and the Bear Stearns' classification were the same, the mean for Street Excluders (Street Includers) would be $1.00(0.00)$. Also, the untabulated correlation between EX_STREET and the footnote file-based indicator variable is 0.42 . More importantly, despite the apparent errors, untabulated findings based on the footnote file indicator variable reveal the same inferences relating to our research questions as those based on EX_STREET.

The footnote file also permits us to obtain some insight into whether the phenomenon we study is limited to forecasts of earnings for 2006, the first year of mandatory expensing; Bear Stearns did not repeat its analysis for forecasts of 2007 earnings. The footnote file indicates that stock-based compensation expense is excluded from the 2007 consensus earnings forecast for 258 firms - a reduction of only ten firms from the 2006 forecast footnote file. This minor reduction suggests that disagreement on whether to include the expense continues and is not a one-year phenomenon associated with the transition to SFAS 123R. 


\subsubsection{Option plan modifications}

Choudhary, Rajgopal, and Venkatachalam (2009) documents that some firms accelerated vesting of employee options, and Brown and Lee (2006) and Johnston and Rock (2006) find that firms cut back on their use of option-based compensation, both in anticipation of mandatory recognition of stock-based compensation expense. A question these studies raise is whether our finding of differences in predictive ability between Street Includers and Street Excluders are driven by cross-sectional differences in firms that accelerate vesting or reduce their reliance on option-based compensation. To provide evidence on this possibility, we obtained data on option grants for 2005 and 2006 from Equilar. We were able to obtain these data for 79 Street Excluders and 1,451 Street Includers. Untabulated statistics reveal that the correlation between the number of options granted in 2005 and 2006 for Street Excluders (Street Includers) is 0.46 (0.47). These statistics do not reveal a systematic difference in option grant changes between the two groups of firms.

\section{Conclusion}

Accounting for stock-based compensation is one of the most controversial topics addressed by accounting standard setters. Statement of Financial Accounting Standards No. 123R requires firms to recognize stock-based compensation expense beginning in 2006. Yet, some firms' managers exclude the expense from pro forma earnings and some firms' analysts exclude it from Street earnings. We seek to understand what explains the differences across firms in the exclusion of stock-based compensation expense from these two earnings measures. We test two explanations for the exclusions-opportunism and predictive ability. Based on the opportunism explanation, we expect that managers are more likely to exclude the expense in order to manage investor perceptions; based on the predictive ability explanation, we expect that 
analysts are more likely to exclude the expense when exclusion results in a measure of earnings that has greater predictive ability for future firm performance.

Regarding opportunism, we find that incentives to increase earnings, smooth earnings, and meet earnings benchmarks are significantly positively related to exclusion from pro forma earnings. However, when we control for exclusion from pro forma earnings, we find that only the incentive to meet earnings benchmarks incrementally explains exclusions from Street earnings. These findings indicate that opportunism explains pro forma exclusions, and that Street exclusions largely are not directly associated with opportunism. Regarding predictive ability, we find earnings that excludes (includes) stock-based compensation expense has significantly greater predictive ability for future earnings for firms whose Street earnings excludes (includes) the expense. However, these findings do not apply to pro forma earnings. In fact, we find the opposite-earnings that includes (excludes) stock-based compensation expense has significantly greater predictive ability for future earnings for firms whose pro forma earnings excludes (includes) the expense. Together, the findings indicate that predictive ability explains analysts' exclusions of stock-based compensation expense from Street earnings, but does not explain managers' exclusions of the expense from pro forma earnings.

By examining how managers and analysts determine pro forma and Street earnings in response to the highly controversial requirements of SFAS $123 \mathrm{R}$, we provide insight into how key market participants respond to changes in GAAP and into the controversy surrounding the recognition of stock-based compensation expense. Our findings indicate that changes in the definition of GAAP earnings are excluded from analysts' earnings forecasts when the change fails to reflect information relevant to predicting the firm's fundamentals, and are excluded from firm's pro forma earnings when the exclusion gives the perception of higher and smoother 
earnings, and aids in meeting earnings benchmarks. Thus, our findings suggest that the controversy may be attributable to cross-sectional variation in the relevance of the expense for equity valuation, as well as to differing incentives of key market participants. 


\section{References}

Aboody, D. 1996. Market valuation of employee stock options. Journal of Accounting and Economics 22: 357-391.

Aboody, D., M. E. Barth, and R. Kasznik. 2004a. SFAS No. 123 stock-based compensation expense and equity market values. The Accounting Review 79 (2): 251-275.

Aboody, D., M. E. Barth, and R. Kasznik. 2004b. Firms' voluntary recognition of stock-based compensation expense. Journal of Accounting Research 42 (2): 123-150.

Accounting Principles Board. 1973. Accounting for Stock Issued to Employees, New York, NY: APB.

Baik, B., D. B. Farber, and K. Petroni. 2009. Analyst incentives and street earnings. Journal of Accounting Research 47(1): 1-25.

Barth, M. E., W. H. Beaver, and W. R. Landsman. 1998. Relative valuation roles of equity book value and net income as a function of financial health. Journal of Accounting and Economics 25 (1): 1-34.

Belsley, D. A., E. Kuh, and R. E. Welsch. 1980. Regression Diagnostics. New York, NY: Wiley.

Blacconiere, W.G., J.R. Frederickson, M.F. Johnson, and M.F. Lewis. 2011. Are voluntary disclosures that disavow the reliability of mandated fair value information informative or opportunistic? Journal of Accounting and Economics. Forthcoming.

Bhattacharya, N., E. L. Black, T. E. Christensen, and C. R. Larson. 2003. Assessing the relative informativeness and permanence of pro forma earnings and GAAP operating earnings. Journal of Accounting and Economics 36: 285-319.

Bradshaw, M. T., and R. G. Sloan. 2002. GAAP versus the Street: An empirical assessment of two alternative definitions of earnings. Journal of Accounting Research 40 (1): 41-66. 
Brown, L. D., and K. Sivakumar. 2003. Comparing the value relevance of two operating income measures. Review of Accounting Studies 8: 561-72.

Brown, L. D., and Y.-J. Lee. 2006. The impact of SFAS 123R on changes in option-based compensation. Working paper, Georgia State University.

Brown, N.C., Christensen, T.E., Elliott, W.B. and R.D. Mergenthaler. 2011. Investor sentiment and pro forma earnings disclosures. Journal of Accounting Research. forthcoming.

Burgstahler, D., and I. Dichev. 1997. Earnings management to avoid earnings decreases and losses. Journal of Accounting and Economics 24: 99-126.

Carter, M. E., and L. J. Lynch. 2003. The consequences of the FASB's 1998 proposal on accounting for stock option repricing." Journal of Accounting \& Economics 35: 51-72.

Choudhary, P., S. Rajgopal and M. Venkatachalam. 2009. Accelerated vesting of employee stock options in anticipation of FAS 123-R. Journal of Accounting Research 47(1):1-42.

Christensen, T. E., K. J. Merkley, J. W. Tucker, and S. Venkataraman. 2011. Do managers use earnings guidance to influence street earnings exclusions? Review of Accounting Studies 16: $501-527$.

Christie, A. A. 1987. On cross-sectional analysis in accounting research. Journal of Accounting and Economics 9(3): 231-258.

Clarke, K. 2003. Nonparametric model discrimination in international relations. Journal of Conflict Resolution 47: 724-774.

Clarke, K. 2007. A simple distribution-free test for nonnested model selection. Political Analysis 15 (3): 347-363.

Cohen, D., R. Hann, and M.Ogneva. 2007. Another look at GAAP versus the Street: an empirical assessment of measurement error bias. Review of Accounting Studies 12 (2-3): 271-303. 
Curtis, A., S. McMahon, S. McVay, and B. Whipple. 2011. Non-GAAP earnings: Informative or opportunistic? An analysis of transitory gains. Working paper. University of Utah.

Doyle, J. T., R. J. Lundholm, and M. T. Soliman. 2003. The predictive value of expenses excluded from pro forma earnings. Review of Accounting Studies 8 (2-3): 145-174.

Financial Accounting Standards Board. 1995. Statement of Financial Accounting Standards No. 123: Accounting for Stock-Based Compensation, Norwalk, CT: FASB.

Financial Accounting Standards Board. 2004. Statement of Financial Accounting Standards No. 123 (revised 2004): Share-based Payment, Norwalk, CT: FASB.

First Call. 1999. Present Methodology for US Earnings Estimates, Company Documentation. New York, NY: First Call.

Francis, J., and D. Philbrick. 1993. Analysts' decisions as a product of a multi-task environment. Journal of Accounting Research 31: 216-230.

Gow, I. D., G. Ormazabal, and D. J. Taylor. 2010. Correcting for both cross-sectional and timeseries dependence in accounting research. The Accounting Review 85(2): 483-512.

Gu, Z., and T. Chen. 2004. Analysts' treatment of nonrecurring items in street earnings. Journal of Accounting and Economics 38: 129-170.

Hanlon, M., S. Rajgopal, and T. Shevlin. 2003. Are executive stock options associated with future earnings. Journal of Accounting and Economics 36: 3-43.

Hagopian, K. 2006. Point of view: Expensing employee stock options is improper accounting. California Management Review 48: 136-156.

Johnston, D., and S. Rock. 2006. The effect of expense recognition on stock option grants and operating performance. Working paper.

Jones, S. D. 2006. Options expensing jars consensus. Wall Street Journal. April 4. 
Kasznik, R., and M. F. McNichols. 2002. Does meeting earnings expectations matter? Evidence from analyst forecast revisions and share prices. Journal of Accounting Research 40 (3): $727-759$.

Kothari, S. P., and J. L. Zimmerman. 1995. Price and return models. Journal of Accounting and Economics 20 (2): 155-192.

Landsman, W. R., B. L. Miller, and S. Yeh. 2007. Implications of components of income excluded from pro forma earnings for future profitability and equity valuation. Journal of Business Finance and Accounting 34 (3-4): 650-675.

Lambert, R. A. 2004. Discussion of 'Analysts' treatment of non-recurring items in Street earnings' and 'Loss function assumptions in rational expectations tests on financial analysts' earnings forecasts'. Journal of Accounting and Economics 38 (1-3): 205-222.

Larcker, D. F., 2003. Discussion of 'Are executive stock options associated with future earnings?' Journal of Accounting and Economics 36: 91-103.

Lin, H., M. F. McNichols. 1998. Underwriting relationships, analysts' earnings forecasts and investment recommendations. Journal of Accounting and Economics 25: 101-127.

Lougee, B., and C. Marquardt. 2004. Earnings informativeness and strategic disclosure: An empirical examination of 'pro forma' net income'. The Accounting Review 79: 769-95.

McConnell, P., J. Pegg, C. Senyek, and D. Mott. 2003. More companies voluntarily adopt fair value expensing of employee stock options. September 4. Bear Stearns Equity Research.

McVay, S. 2006. Earnings management using classification shifting: An examination of core earnings and special items. The Accounting Review 81 (3): 501-531.

Michaely, R., and K.Womack. 1999. Conflict of interest and the credibility of underwriter analyst recommendations. Review of Financial Studies 12: 653-86. 
Philbrick, D., and W. Ricks. 1991. Using Value Line and IBES analyst forecasts in accounting research. Journal of Accounting Research 29: 397-417.

Piotroski, J. 2000. Value investing: The use of historical financial statement information to separate winners from losers. Journal of Accounting Research 38 (Supplement): 1-41.

Richardson, S., S. H. Teoh, and P. D. Wysocki. 2004. The walk-down to beatable analyst forecasts: The role of equity issuance and insider trading incentives. Contemporary Accounting Research 21 (4): 885-924.

Riedl, E.J. 2004. An examination of long-lived asset impairments. Accounting Review : 858.

Srinivasan, S., and E.J. Riedl. 2010. Signaling firm performance through financial statement presentation: An analysis using special items. Contemporary Accounting Research 27: 289332.

Senyek, C., J. Pegg, D. Mott, and A. Calingasan. 2007. Consensus estimates exclude stock-based compensation expense for 32\% of NASDAQ 100 companies. January 16. Bear Stearns Equity Research.

Vuong, Q. 1989. Likelihood ratio tests for model selection and non-nested hypotheses. Econometrica 57 (2): 307-333.

Wooldridge, J. 2001. Econometric Analysis of Cross Section and Panel Data. MIT Press. 
Table 1

Descriptive Statistics

Panel A. Number of Street and Pro Forma Earnings Includer and Excluder Firms

\begin{tabular}{llrrr} 
& & \multicolumn{2}{c}{ Street Earnings } & \\
\cline { 3 - 4 } Pro Forma Earnings & & Includers & Excluders & \multicolumn{1}{c}{ Total } \\
\cline { 3 - 5 } & Includers & 1,496 & 5 & 1,501 \\
& Excluders & 251 & 93 & 344 \\
\cline { 2 - 5 } & Total & 1,747 & 98 & 1,845
\end{tabular}

Panel B. Industry Classification of Sample Firms

\begin{tabular}{|c|c|c|c|c|c|}
\hline \multirow[b]{2}{*}{ Industry } & \multicolumn{2}{|c|}{ Pro Forma } & \multicolumn{2}{|c|}{ Street } & \multirow[b]{2}{*}{ Total } \\
\hline & Includers & Excluders & Includers & Excluders & \\
\hline Pharmaceuticals & 182 & 24 & 197 & 9 & 206 \\
\hline Durable Manufacturers & 450 & 79 & 516 & 13 & 529 \\
\hline Computers & 252 & 170 & 352 & 70 & 422 \\
\hline Transportation & 150 & 10 & 159 & 1 & 160 \\
\hline Retail & 229 & 23 & 250 & 2 & 252 \\
\hline Insurance and Real Estate & 16 & 5 & 20 & 1 & 21 \\
\hline Services & 222 & 33 & 253 & 2 & 255 \\
\hline Total & 1,501 & 344 & 1,747 & 98 & 1,845 \\
\hline
\end{tabular}


Table 1 (continued)

Descriptive Statistics

Panel C. Descriptive Statistics - Pro Forma Excluders and Includers

\begin{tabular}{|c|c|c|c|c|c|c|c|c|}
\hline \multirow[b]{2}{*}{ Variable } & \multicolumn{3}{|c|}{ Pro Forma Excluders (344 firms) } & \multicolumn{3}{|c|}{ Pro Forma Includers (1,501 firms) } & \multirow[b]{2}{*}{$t$-stat. } & \multirow[b]{2}{*}{ Wilcoxon Z } \\
\hline & Mean & Median & Std. Dev. & Mean & Median & Std. Dev. & & \\
\hline COMPXA & 0.03 & 0.02 & 0.03 & 0.02 & 0.01 & 0.03 & 5.86 & 11.33 \\
\hline IPOSSURP & 0.76 & 1.00 & 0.43 & 0.65 & 1.00 & 0.48 & 4.03 & 4.01 \\
\hline ILOSS & 0.11 & 0.00 & 0.32 & 0.05 & 0.00 & 0.22 & 4.43 & 4.40 \\
\hline$\sigma(C O M P X A)$ & 0.02 & 0.01 & 0.06 & 0.01 & 0.00 & 0.03 & 6.24 & 11.50 \\
\hline$\sigma(A F)$ & 0.00 & 0.00 & 0.01 & 0.01 & 0.00 & 0.05 & -1.90 & -1.46 \\
\hline ANALYSTS & 10.43 & 8.00 & 7.69 & 7.38 & 5.00 & 5.86 & 8.18 & 7.50 \\
\hline INSTIT & 0.71 & 0.77 & 0.25 & 0.66 & 0.72 & 0.27 & 3.24 & 3.09 \\
\hline POLICY & 0.62 & 1.00 & 0.49 & 0.56 & 1.00 & 0.50 & 2.10 & 2.10 \\
\hline$E A R N$ & 0.05 & 0.07 & 0.13 & -0.03 & 0.05 & 0.36 & 4.06 & 6.05 \\
\hline$S I Z E$ & 7.00 & 6.84 & 1.44 & 6.65 & 6.47 & 1.52 & 3.92 & 4.12 \\
\hline$B M$ & 0.35 & 0.31 & 0.26 & 0.43 & 0.38 & 0.46 & -3.22 & -4.44 \\
\hline EX_STREET & 0.27 & 0.00 & 0.44 & 0.00 & 0.00 & 0.06 & 22.47 & 19.91 \\
\hline
\end{tabular}


Table 1 (continued)

Descriptive Statistics

Panel D. Descriptive Statistics - Street Excluders and Includers

\begin{tabular}{|c|c|c|c|c|c|c|c|c|}
\hline \multirow[b]{2}{*}{ Variable } & \multicolumn{3}{|c|}{ Street Excluders (98 firms) } & \multicolumn{3}{|c|}{ Street Includers (1,747 firms) } & \multirow[b]{2}{*}{$t$-stat } & \multirow[b]{2}{*}{ Wilcoxon Z } \\
\hline & Mean & Median & Std. Dev. & Mean & Median & Std. Dev. & & \\
\hline COMPXA & 0.03 & 0.02 & 0.02 & 0.02 & 0.01 & 0.03 & 1.94 & 6.30 \\
\hline IPOSSURP & 0.83 & 1.00 & 0.38 & 0.66 & 1.00 & 0.47 & 3.46 & 3.45 \\
\hline ILOSS & 0.11 & 0.00 & 0.32 & 0.06 & 0.00 & 0.24 & 2.13 & 2.13 \\
\hline$\sigma(C O M P X A)$ & 0.02 & 0.01 & 0.03 & 0.01 & 0.004 & 0.04 & 2.21 & 7.49 \\
\hline$\sigma(A F)$ & 0.002 & 0.001 & 0.002 & 0.01 & 0.002 & 0.04 & -1.42 & -2.55 \\
\hline ANALYSTS & 16.81 & 15.00 & 8.44 & 7.46 & 5.00 & 5.83 & 15.03 & 11.26 \\
\hline INSTIT & 0.75 & 0.79 & 0.23 & 0.66 & 0.73 & 0.27 & 3.09 & 3.02 \\
\hline POLICY & 0.86 & 1.00 & 0.35 & 0.55 & 1.00 & 0.50 & 5.98 & 5.93 \\
\hline$E A R N$ & 0.08 & 0.07 & 0.06 & -0.02 & 0.05 & 0.34 & 2.69 & 4.55 \\
\hline$S I Z E$ & 8.13 & 7.90 & 1.35 & 6.64 & 6.47 & 1.48 & 9.74 & 9.46 \\
\hline$B M$ & 0.34 & 0.30 & 0.20 & 0.42 & 0.36 & 0.44 & -1.75 & -2.78 \\
\hline EX_PROFORMA & 0.95 & 1.00 & 0.22 & 0.14 & 0.00 & 0.35 & 22.47 & 19.91 \\
\hline
\end{tabular}


Table 1 (continued)

Descriptive Statistics

Panel E. Correlation Matrix

\begin{tabular}{|c|c|c|c|c|c|c|c|c|c|c|c|c|c|}
\hline & 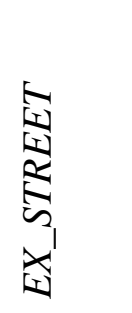 & 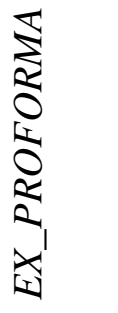 & 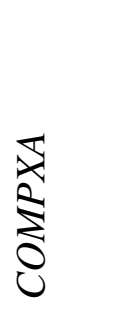 & $\begin{array}{l}2 \\
\vdots \\
5 \\
\vdots \\
\vdots \\
\vdots\end{array}$ & 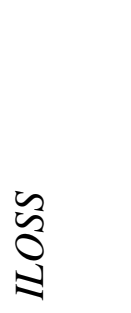 & 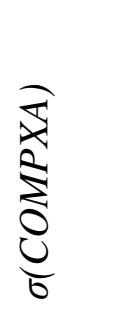 & $\frac{\mathbb{S}}{6}$ & $\begin{array}{l}\tilde{L} \\
\vdots \\
\vdots \\
z \\
z\end{array}$ & $\underset{⿱ 亠 幺}{\vdots}$ & 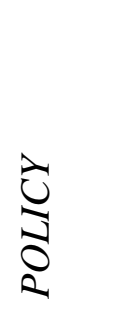 & 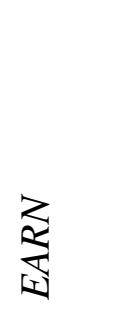 & $\underset{\sim}{\mathbb{N}}$ & $\sum_{\infty}$ \\
\hline EX_STREET & & 0.46 & 0.15 & 0.08 & 0.05 & 0.05 & -0.03 & 0.33 & 0.07 & 0.14 & 0.11 & 0.22 & -0.06 \\
\hline EX_PROFORMA & 0.46 & & 0.26 & 0.09 & 0.10 & 0.14 & -0.04 & 0.19 & 0.08 & 0.05 & 0.14 & 0.10 & -0.10 \\
\hline СOMPXА & 0.05 & 0.14 & & -0.05 & 0.31 & 0.47 & 0.13 & -0.06 & -0.18 & -0.19 & -0.18 & -0.34 & -0.22 \\
\hline IPOSSURP & 0.08 & 0.09 & -0.01 & & 0.01 & 0.02 & -0.06 & 0.11 & 0.04 & 0.08 & 0.23 & 0.16 & -0.08 \\
\hline ILOSS & 0.05 & 0.10 & 0.28 & 0.01 & & 0.16 & 0.01 & -0.04 & -0.02 & -0.07 & -0.13 & -0.15 & 0.06 \\
\hline$\sigma(C O M P X A)$ & 0.18 & 0.27 & 0.86 & 0.02 & 0.24 & & 0.05 & -0.03 & -0.17 & -0.12 & -0.19 & -0.31 & -0.23 \\
\hline$\sigma(A F)$ & -0.06 & -0.03 & 0.39 & -0.12 & 0.09 & 0.41 & & -0.10 & -0.16 & -0.06 & -0.32 & -0.40 & -0.21 \\
\hline ANALYSTS & 0.26 & 0.18 & -0.01 & 0.11 & -0.04 & 0.00 & -0.21 & & 0.36 & 0.51 & 0.26 & 0.69 & -0.17 \\
\hline INSTIT & 0.07 & 0.07 & -0.14 & 0.03 & -0.03 & -0.17 & -0.33 & 0.26 & & 0.28 & 0.20 & 0.41 & 0.03 \\
\hline POLICY & 0.14 & 0.05 & -0.22 & 0.08 & -0.07 & -0.19 & -0.20 & 0.58 & 0.29 & & 0.12 & 0.58 & -0.07 \\
\hline$E A R N$ & 0.06 & 0.09 & -0.23 & 0.14 & 0.03 & -0.12 & -0.53 & 0.16 & 0.25 & 0.10 & & 0.29 & 0.08 \\
\hline SIZE & 0.22 & 0.09 & -0.28 & 0.16 & -0.14 & -0.17 & -0.15 & 0.72 & 0.37 & 0.56 & 0.44 & & -0.14 \\
\hline$B M$ & -0.04 & -0.07 & -0.12 & -0.07 & 0.07 & -0.09 & -0.06 & -0.11 & 0.03 & -0.04 & -0.24 & -0.22 & \\
\hline
\end{tabular}

EX_STREET (EX_PROFORMA) is an indicator variable that equals one if the firm's Street earnings forecast (pro forma earnings report) for fiscal 2006 excludes stock-based compensation expense, and zero otherwise. We label firms with $E X \_S T R E E T$ equal to one (zero) as Street Excluders (Street Includers), and firms with EX_PROFORMA equal to one (zero) as Pro Forma Excluders (Pro Forma Includers). COMPXA is COMPX, implied option expense (data \#399), divided by beginning of year total assets. IPOSSURP equals one if $N I$, actual earnings as reported by $\mathrm{I} / \mathrm{B} / \mathrm{E} / \mathrm{S}$, minus the last consensus earnings forecast before year-end is positive, and zero otherwise. ILOSS equals one if $N I$ minus COMPX is negative and NI is non-negative, and zero otherwise. $\sigma(C O M P X A)$ is the 
standard deviation of a firm's COMPXA for available years in 1998-2005. $\sigma(A F)$ is the standard deviation of analyst forecasts for the firm deflated by total assets. ANALYSTS is the number of analysts with forecasts for the firm. INSTIT is the percent of shares outstanding held by Form 13-F filers from Thomson Financial. POLICY is an indicator variable that equals one if the firm is covered by at least one of seven large brokerage firms that the popular press reports require their analysts to include stock-based compensation expense in their earnings forecasts, and zero otherwise. EARN is net income before extraordinary items (data \#18), deflated by beginning of year total assets (data \#6). SIZE is the natural logarithm of market value of equity. BM is year-end ratio of equity book value to market value. Unless otherwise noted, all variables are for 2005 and are in millions of dollars. In panel B, industries are defined as in Barth, Beaver, and Landsman (1998). In panels C and D, the $t$-statistic (Wilcoxon $Z$ ) tests for a difference in means (ranks) across the two samples. In panel E, the Pearson (Spearman) correlations appear above (below) the diagonal. Sample of 1,845 firms, comprising 98 (344) Street (Pro Forma) Excluders and 1,747 (1,501) Street (Pro Forma) in the same industries. 
Table 2

Likelihood of Exclusion of Stock-based Compensation Expense

$$
\begin{gathered}
E X=\beta_{0}+\beta_{1} \text { COMPXA }+\beta_{2} \text { IPOSSURP }+\beta_{3} I L O S S+\beta_{4} \sigma(C O M P X A)+\beta_{5} \sigma(A F) \\
+\beta_{6} \text { ANALYSTS }+\beta_{7} \text { INSTIT }+\beta_{8} P O L I C Y+\beta_{9} R O A+\beta_{10} S I Z E+\varepsilon
\end{gathered}
$$

\begin{tabular}{|c|c|c|c|c|c|c|c|c|}
\hline \multirow[b]{3}{*}{ Variable } & \multicolumn{4}{|c|}{ Management Exclusions } & \multicolumn{4}{|c|}{ Analyst Exclusions } \\
\hline & \multicolumn{2}{|c|}{$E X=E X \_P R O F O R M A$} & \multicolumn{2}{|c|}{$E X=E X \_P R O F O R M A$} & \multicolumn{2}{|c|}{$E X=E X \_S T R E E T$} & \multicolumn{2}{|c|}{$E X=E X \_S T R E E T$} \\
\hline & coef. & $t$-stat. & coef. & $t$-stat. & coef. & $t$-stat. & coef. & $t$-stat. \\
\hline СOMPXA & 5.57 & $(3.54)$ & 5.22 & $(3.42)$ & 5.98 & $(3.55)$ & 2.03 & $(0.75)$ \\
\hline IPOSSURP & 0.22 & $(2.75)$ & 0.18 & $(2.11)$ & 0.29 & $(2.14)$ & 0.37 & $(1.91)$ \\
\hline ILOSS & 0.18 & $(1.23)$ & 0.10 & $(0.65)$ & 0.32 & $(1.43)$ & 0.33 & $(1.30)$ \\
\hline$\sigma(C O M P X A)$ & 4.27 & $(3.41)$ & 3.64 & $(3.22)$ & 2.18 & (1.96) & 0.52 & $(0.53)$ \\
\hline$\sigma(A F)$ & 0.01 & $(0.00)$ & 0.30 & $(0.14)$ & -48.56 & $(-2.08)$ & -50.95 & $(-1.85)$ \\
\hline ANALYSTS & 0.04 & $(5.64)$ & 0.02 & $(2.36)$ & 0.07 & $(6.46)$ & 0.05 & (4.30) \\
\hline INSTIT & 0.32 & $(2.02)$ & 0.37 & $(2.15)$ & 0.20 & $(0.74)$ & 0.10 & $(0.30)$ \\
\hline POLICY & -0.02 & $(-0.17)$ & 0.002 & $(0.02)$ & 0.12 & $(0.67)$ & 0.17 & $(0.78)$ \\
\hline$R O A$ & 1.45 & (4.19) & 1.42 & $(4.00)$ & 0.94 & $(1.73)$ & -0.52 & $(-1.00)$ \\
\hline SIZE & -0.08 & $(-2.28)$ & -0.12 & $(-2.88)$ & 0.03 & $(0.56)$ & 0.21 & $(2.82)$ \\
\hline EX_STREET & & & 2.55 & (11.37) & & & & \\
\hline EX_PROFORMA & & & & & & & 2.33 & $(8.77)$ \\
\hline Pseudo $\mathrm{R}^{2}$ & & $1 \%$ & & $25 \%$ & & $66 \%$ & & $25 \%$ \\
\hline
\end{tabular}

EX_PROFORMA (EX_STREET) is an indicator variable that equals one if the firm's pro forma earnings report (Street earnings forecast) for fiscal 2006 excludes stock-based compensation expense, and zero otherwise. We label firms with EX_STREET equal to one (zero) as Street Excluders (Street Includers), and firms with EX_PROFORMA equal to one (zero) as Pro Forma Excluders (NonPro Forma Includers). All other variables are as previously defined and are from 2005. $t$-statistics in parentheses are based on standard errors clustered by firm and year. Sample of 1,845 firms, comprising 98 (344) Street (Pro Forma) Excluders and 1,747 $(1,501)$ Street (Pro Forma) in the same industries. 
Table 3

Differences in Predictive Ability

Panel A. Pro Forma Exclusions

Model 1: $\quad E A R N_{t+1}=\alpha_{0}+\alpha_{1} E A R N_{t}+\alpha_{2} S I Z E_{t}+\alpha_{3} B M_{t}+\varepsilon_{t}$

Model 2: $\quad E A R N_{t+1}=\alpha_{0}+\alpha_{1}\left(E A R N_{t}-C O M P X A_{t}\right)+\alpha_{2} S I Z E_{t}+\alpha_{3} B M_{t}+\varepsilon_{t}$

\begin{tabular}{|c|c|c|c|c|}
\hline \multirow[b]{2}{*}{ Variable } & \multicolumn{2}{|c|}{$\begin{array}{l}\text { Pro Forma Excluders } \\
\qquad(\mathrm{N}=1,742)\end{array}$} & \multicolumn{2}{|c|}{$\begin{array}{l}\text { Pro Forma Includers } \\
\qquad(\mathrm{N}=6,664)\end{array}$} \\
\hline & Model 1 & Model 2 & Model 1 & Model 2 \\
\hline$E A R N_{t}$ & $\begin{array}{c}0.17 \\
(3.79)\end{array}$ & $\begin{array}{c}0.17 \\
(3.93)\end{array}$ & $\begin{array}{c}0.44 \\
(12.64)\end{array}$ & $\begin{array}{c}0.40 \\
(10.06)\end{array}$ \\
\hline SIZE & $\begin{array}{c}0.01 \\
(2.08)\end{array}$ & $\begin{array}{c}0.01 \\
(2.34)\end{array}$ & $\begin{array}{c}0.003 \\
(1.81)\end{array}$ & $\begin{array}{c}0.003 \\
(1.68)\end{array}$ \\
\hline$B M$ & $\begin{array}{l}-0.07 \\
(-5.89)\end{array}$ & $\begin{array}{l}-0.08 \\
(-5.86)\end{array}$ & $\begin{array}{l}-0.03 \\
(-5.38)\end{array}$ & $\begin{array}{l}-0.03 \\
(-5.77)\end{array}$ \\
\hline Adjusted $\mathrm{R}^{2}$ & 28.64 & 30.16 & 46.88 & 45.61 \\
\hline $\begin{array}{l}\text { Goodness-of-fit predictions } \\
\text { Adj. } \mathrm{R}^{2}: \text { Model } 1-\text { Model } 2 \\
p \text {-value }\end{array}$ & \multicolumn{2}{|c|}{$\begin{array}{l}\text { Model } 1=\text { Model } 2 \\
\quad-1.52 \\
<0.01\end{array}$} & \multicolumn{2}{|c|}{$\begin{array}{l}\text { Model } 1=\text { Model } 2 \\
1.27 \\
<0.01\end{array}$} \\
\hline \multicolumn{5}{|l|}{ Panel B. Street Exclusions } \\
\hline \multicolumn{5}{|c|}{$\begin{array}{l}E A R N_{t+1}=\alpha_{0}+\alpha_{1} E A R N_{t}+\alpha_{2} \operatorname{SIZE}_{t}+\alpha_{3} B M_{t}+\varepsilon_{t} \\
E A R N_{t+1}=\alpha_{0}+\alpha_{1}\left(E A R N_{t}-\operatorname{COMPXA}_{t}\right)+\alpha_{2} \operatorname{SIZE}_{t}+\alpha_{3} B M_{t}+\varepsilon_{t}\end{array}$} \\
\hline \multirow{2}{*}{\multicolumn{5}{|c|}{$\begin{array}{lrr}\text { Model 2: } & \text { EARN }_{t+1}=\alpha_{0}+\alpha_{1}\left(E A R N_{t}-C O M P X A_{t}\right)+\alpha_{2} S I Z E_{t}+\alpha_{3} B M_{t}+\varepsilon_{t} \\
& \text { Street Excluders } & \text { Street Includers } \\
\text { Variable } & (\mathrm{N}=601) & (\mathrm{N}=7,805) \\
\text { Model } 1 \quad \text { Model 2 } & \text { Model 1 }\end{array}$}} \\
\hline & & & & \\
\hline$\overline{E A R N_{t}}$ & $\begin{array}{c}0.27 \\
(11.37)\end{array}$ & $\begin{array}{c}0.22 \\
(7.59)\end{array}$ & $\begin{array}{c}0.40 \\
(15.51)\end{array}$ & $\begin{array}{c}0.38 \\
(15.54)\end{array}$ \\
\hline$S I Z E$ & $\begin{array}{c}0.001 \\
(0.16)\end{array}$ & $\begin{array}{c}0.003 \\
(0.36)\end{array}$ & $\begin{array}{c}0.005 \\
(2.55)\end{array}$ & $\begin{array}{c}0.004 \\
(2.30)\end{array}$ \\
\hline$B M$ & $\begin{array}{l}-0.10 \\
(-2.21)\end{array}$ & $\begin{array}{l}-0.13 \\
(-2.33)\end{array}$ & $\begin{array}{l}-0.02 \\
(-3.07)\end{array}$ & $\begin{array}{l}-0.03 \\
(-3.13)\end{array}$ \\
\hline$\overline{\text { Adjusted } \mathrm{R}^{2}}$ & $36.23 \%$ & $35.25 \%$ & $42.77 \%$ & $43.63 \%$ \\
\hline $\begin{array}{l}\text { Goodness-of-fit predictions } \\
\text { Adj. } \mathrm{R}^{2}: \text { Model } 1-\text { Model } 2 \\
p \text {-value }\end{array}$ & \multicolumn{2}{|c|}{$\begin{array}{l}\text { Model } 1>\text { Model } 2 \\
0.98 \\
<0.01\end{array}$} & \multicolumn{2}{|c|}{$\begin{array}{l}\text { Model } 1<\text { Model } 2 \\
\quad-0.86 \\
<0.01\end{array}$} \\
\hline
\end{tabular}

EX_PROFORMA (EX_STREET) is an indicator variable that equals one if the firm's pro forma earnings report (Street earnings forecast) for fiscal 2006 excludes stock-based compensation 
expense, and zero otherwise. We label firms with EX_STREET equal to one (zero) as Street Excluders (Street Includers), and firms with EX_PROFORMA equal to one (zero) as Pro Forma Excluders (Pro Forma Includers). Sample of 8,406 observations of 1,845 firms, comprising 98 (344) Street (Pro Forma) Excluders and 1,747 (1,501) Street (Pro Forma Includers) in the same industries. $t$ denotes year from 1998 to 2004. Model 1 (Model 2) excludes (includes) stockbased compensation expense as a predictor of future EARN. The $p$-value for the Clarke (2003, 2007) non-parametric test of the null hypothesis that the goodness of fit of Model 1 equals that of Model 2 appears below each pair of regressions. All variables are as previously defined. All regressions include industry and year fixed effects. $t$-statistics in parentheses are based on standard errors clustered by firm and year. 
Table 4

Stock-based Compensation Expense as a Predictor of Firm Performance

Panel A. Future Performance

$E A R N_{t+1}=\alpha_{0}+\alpha_{1} E_{A R N_{t}}+\alpha_{2} \operatorname{COMPXA}_{t}+\varphi_{0} E X+\varphi_{1} E X^{*} C O M P X A_{t}+\alpha_{3} \operatorname{SIZE}_{t}+\alpha_{4}$ BM $_{t}+\varepsilon_{t}$

\begin{tabular}{lccc}
\hline \multicolumn{1}{c}{ Variable } & & $E X=E X \_P R O F O R M A$ & $E X=E X \_S T R E E T$ \\
\hline AARN $_{t}$ & 0.37 & 0.36 & 0.39 \\
COMPXA $A_{t}$ & $(15.22)$ & $(10.65)$ & $(22.78)$ \\
& -0.22 & -0.37 & -0.22 \\
$E X$ & $(-2.30)$ & $(-4.08)$ & $(-2.60)$ \\
& & 0.003 & -0.002 \\
$E X^{*}$ COMPXA & & $(0.36)$ & $(-0.38)$ \\
& & 0.23 & 0.23 \\
SIZE & & $(1.38)$ & $(2.28)$ \\
& & 0.004 & 0.003 \\
$B M$ & $(2.29)$ & $(2.60)$ & $(2.03)$ \\
& -0.03 & -0.03 & -0.03 \\
Adjusted $\mathrm{R}^{2}$ & $(-6.04)$ & $(-6.53)$ & $(-5.75)$ \\
$\alpha_{2}+\varphi_{1}$ & $42.45 \%$ & 42.05 & $43.44 \%$ \\
$p$-value: $\alpha_{2}+\varphi_{1}=0$ & & -0.14 & 0.01 \\
& & $<0.01$ & 0.78 \\
\hline
\end{tabular}


Table 4 (continued)

Stock-based Compensation Expense as a Predictor of Firm Performance

Panel B. Changes in Future Performance

$$
\begin{aligned}
\triangle E A R N_{t+1} & =\alpha_{0}+\alpha_{1} \Delta E A R N_{t}+\alpha_{2} \Delta C O M P X A_{t}+\varphi_{0} E X+\varphi_{1} E X^{*} \Delta C O M P X A_{t} \\
& +\alpha_{3} \operatorname{SIZE}_{t}+\alpha_{4} B M_{t}+\varepsilon_{t}
\end{aligned}
$$

\begin{tabular}{|c|c|c|c|}
\hline Variable & & $E X=E X \_P R O F O R M A$ & $E X=E X$ STREET \\
\hline$\overline{\Delta E A R N_{t}}$ & $\begin{array}{l}-0.02 \\
(-0.66)\end{array}$ & $\begin{array}{l}-0.01 \\
(-0.47)\end{array}$ & $\begin{array}{c}-0.02 \\
(-0.79)\end{array}$ \\
\hline$\triangle C O M P X A_{t}$ & $\begin{array}{c}-0.41 \\
(-3.88)\end{array}$ & $\begin{array}{l}-0.73 \\
(-5.38)\end{array}$ & $\begin{array}{l}-0.47 \\
(-4.54)\end{array}$ \\
\hline$E X$ & & $\begin{array}{c}0.02 \\
(1.90)\end{array}$ & $\begin{array}{c}0.02 \\
(1.85)\end{array}$ \\
\hline$E X^{*} \triangle C O M P X A_{t}$ & & $\begin{array}{c}0.59 \\
(1.47)\end{array}$ & $\begin{array}{c}0.45 \\
(2.99)\end{array}$ \\
\hline $\operatorname{SIZE}_{t}$ & $\begin{array}{l}-0.01 \\
(-3.27)\end{array}$ & $\begin{array}{l}-0.01 \\
(-3.30)\end{array}$ & $\begin{array}{l}-0.01 \\
(-3.28)\end{array}$ \\
\hline$B M_{t}$ & $\begin{array}{l}-0.02 \\
(-2.77)\end{array}$ & $\begin{array}{l}-0.02 \\
(-2.70)\end{array}$ & $\begin{array}{l}-0.02 \\
(-2.75)\end{array}$ \\
\hline$\overline{\text { Adjusted } \mathrm{R}^{2}}$ & $7.05 \%$ & $7.31 \%$ & $7.15 \%$ \\
\hline$\alpha_{2}+\varphi_{1}$ & & -0.14 & -0.02 \\
\hline$p$-value: $\alpha_{2}+\varphi_{1}=0$ & & $<0.01$ & 0.60 \\
\hline
\end{tabular}

EX_PROFORMA (EX_STREET) is an indicator variable that equals one if the firm's pro forma earnings report (Street earnings forecast) for fiscal 2006 excludes stock-based compensation expense, and zero otherwise. We label firms with EX_STREET equal to one (zero) as Street Excluders (Street Includers), and firms with EX_PROFORMA equal to one (zero) as Pro Forma Excluders (Pro Forma Includers). Sample of 8,406 observations for 1,845 firms, comprising 98 (344) Street (Pro Forma) Excluders and 1,747 (1,501) Street (Pro Forma) Includers in the same industries. All variables are as previously defined. $t$ denotes year from 1998 to 2004 and $\Delta$ denotes annual change. Regressions in both panels include industry and year fixed effects. $t$ statistics in parentheses are based on standard errors clustered by firm and year. 
Table 5

Additional Analyses: Decomposition of Exclusion from Street Earnings.

$$
\begin{aligned}
E_{A R N_{t+1}=} \alpha_{0} & +\alpha_{1} E A R N_{t}+\alpha_{2} C O M P X A_{t}+\varphi_{0} E X \_P R E D+\varphi_{1} E X \_P R E D^{*} C O M P X A_{t} \\
& +\varphi_{2} E X \_R E S+\varphi_{3} E X \_R E S^{*} C O M P X A_{t}+\alpha_{3} S I Z E_{t}+\alpha_{4} B M_{t}+\varepsilon_{t} \\
\qquad E A R N_{t+1} & =\alpha_{0}+\alpha_{1} \Delta E A R N_{t}+\alpha_{2} \Delta C O M P X A_{t}+\varphi_{0} E X \_P R E D+\varphi_{1} E X \_P R E D^{*} \Delta C O M P X A_{t} \\
& +\varphi_{2} E X \_R E S+\varphi_{3} E X \_R E S^{*} \Delta C O M P X A_{t}+\alpha_{3} S I Z E_{t}+\alpha_{4} B M_{t}+\varepsilon_{t}
\end{aligned}
$$

\begin{tabular}{lcc}
\hline \multicolumn{1}{c}{ Variable } & $E A R N_{t+1}$ & $\Delta E A R N_{t+1}$ \\
\hline EARN $_{t}$ & 0.39 & -0.03 \\
COMPXA $A_{t}$ & $(21.30)$ & $(-1.28)$ \\
& -0.24 & -0.48 \\
$E X \_P R E D$ & $(-2.31)$ & $(-3.56)$ \\
& 0.14 & 0.23 \\
EX_PRED ${ }^{*} C O M P X A_{t}$ & $(7.91)$ & $(7.58)$ \\
& 0.16 & 0.30 \\
EX_RES & $(0.56)$ & $(0.36)$ \\
& -0.02 & 0.001 \\
EX_RES*COMPXA & $(-2.05)$ & $(0.15)$ \\
& 0.26 & 0.49 \\
SIZE & $(2.85)$ & $(2.31)$ \\
& -0.01 & -0.02 \\
BM & $(-1.13)$ & $(-5.16)$ \\
& -0.03 & -0.02 \\
Adjusted R $^{2}$ & $(-5.67)$ & $(-2.70)$ \\
\hline
\end{tabular}

$E X$ is an indicator variable that equals one if the I/B/E/S consensus forecast of 2006 earnings excludes options expense, and zero otherwise. $E X \_P R E D\left(E X \_R E S\right)$ is the fitted value (residual) from the regression reported in table 2 as Model 2. All other variables are as defined in table 1. Regressions include industry and year fixed effects. $t$-statistics in parentheses are based on standard errors clustered by firm and year. $t$ denotes year from 1998 to 2004 . Sample of 8,406 observations for 98 firms for which the consensus analyst forecast of 2006 earnings excludes stock-based compensation expense (Street Excluders) and 1,747 other firms on I/B/E/S in the same industries (Street Includers). 
Table 6

Additional Analyses: Computer Firms and Non-Computer Firms.

Panel A. Likelihood of Exclusion of Stock-based Compensation Expense

$$
\begin{gathered}
E X=\beta_{0}+\beta_{1} \text { COMPXA }+\beta_{2} \text { IPOSSURP }+\beta_{3} I L O S S+\beta_{4} \sigma(C O M P X A)+\beta_{5} \sigma(A F) \\
+\beta_{6} \text { ANALYSTS }+\beta_{7} I N S T I T+\beta_{8} P O L I C Y+\beta_{9} \text { SIZE }+\beta_{10} R O A+\varepsilon
\end{gathered}
$$

\begin{tabular}{|c|c|c|c|c|}
\hline \multirow[b]{2}{*}{ Variable } & \multicolumn{2}{|c|}{$E X=E X \_P R O F O R M A$} & \multicolumn{2}{|c|}{$E X=E X \_S T R E E T$} \\
\hline & Computers & Non-Computers & Computers & Non-Computers \\
\hline \multirow[t]{2}{*}{ СОМРXА } & 2.92 & 5.58 & 3.03 & -5.76 \\
\hline & $(1.20)$ & $(2.92)$ & $(0.69)$ & $(-1.51)$ \\
\hline \multirow[t]{2}{*}{ IPOSSURP } & 0.32 & 0.10 & 0.18 & 0.41 \\
\hline & (1.97) & $(1.05)$ & $(0.61)$ & $(1.67)$ \\
\hline \multirow[t]{2}{*}{ ILOSS } & -0.21 & 0.44 & 0.30 & 0.47 \\
\hline & $(-0.97)$ & $(2.29)$ & $(0.98)$ & $(1.07)$ \\
\hline \multirow[t]{2}{*}{$\sigma(C O M P X)$} & 2.43 & 4.19 & -1.34 & 16.91 \\
\hline & $(2.25)$ & $(1.33)$ & $(-0.91)$ & (4.18) \\
\hline \multirow[t]{2}{*}{$\sigma(A F)$} & 2.87 & 0.01 & -70.62 & -34.06 \\
\hline & $(0.26)$ & $(0.00)$ & $(-1.45)$ & $(-0.93)$ \\
\hline \multirow[t]{2}{*}{ ANALYSTS } & 0.04 & 0.02 & 0.02 & 0.06 \\
\hline & $(2.88)$ & $(2.12)$ & $(1.23)$ & $(2.60)$ \\
\hline \multirow[t]{2}{*}{ INSTIT } & 0.58 & 0.35 & 0.70 & 0.20 \\
\hline & $(2.10)$ & $(1.70)$ & $(1.37)$ & $(0.42)$ \\
\hline \multirow[t]{2}{*}{ POLICY } & -0.03 & 0.03 & 0.66 & -0.35 \\
\hline & $(-0.15)$ & $(0.28)$ & $(2.05)$ & $(-0.93)$ \\
\hline \multirow[t]{2}{*}{$S I Z E$} & -0.03 & -0.03 & 0.23 & 0.39 \\
\hline & $(-0.45)$ & $(-0.67)$ & $(2.27)$ & $(2.97)$ \\
\hline \multirow[t]{2}{*}{$R O A$} & 1.40 & 1.15 & -1.00 & -0.88 \\
\hline & (1.69) & $(2.98)$ & $(-0.66)$ & $(-1.68)$ \\
\hline \multirow[t]{2}{*}{ EX_PROFORMA } & & & 2.14 & 2.66 \\
\hline & & & $(6.44)$ & $(4.80)$ \\
\hline McFadden $\mathrm{R}^{2}$ & $9.48 \%$ & $6.24 \%$ & $49.18 \%$ & $54.99 \%$ \\
\hline
\end{tabular}


Table 6 (continued)

Additional Analyses: Computer Firms and Non-Computer Firms.

Panel B: Stock-based Compensation Expense as a Predictor of Future Operating Performance,

$E A R N_{t+1}=\alpha_{0}+\alpha_{1} E A R N_{t}+\alpha_{2} \operatorname{COMPXA}_{t}+\varphi_{0} E X+\varphi_{1} E X^{*} C O M P X A_{t}+\alpha_{3} S I Z E_{t}+\alpha_{4} B M_{t}+\varepsilon_{t}$

\begin{tabular}{lcccc}
\hline & \multicolumn{2}{c}{$E X=E X \_P R O F O R M A$} & \multicolumn{2}{c}{$E X=E X \_$STREET } \\
\multicolumn{1}{c}{ Variable } & Computers & Non-Computers & Computers & Non-Computers \\
\hline EARN $_{t}$ & 0.16 & 0.45 & 0.16 & 0.46 \\
COMPXA & $(3.84)$ & $(20.51)$ & $(3.76)$ & $(19.71)$ \\
& -0.52 & -0.42 & -0.37 & -0.57 \\
$E X$ & $(-2.37)$ & $(-2.73)$ & $(-2.38)$ & $(-3.42)$ \\
& 0.004 & 0.01 & 0.01 & -0.04 \\
$E X^{*}$ COMPXA & $(0.31)$ & $(1.19)$ & $(0.74)$ & $(-3.16)$ \\
& 0.37 & -0.14 & 0.29 & 0.88 \\
$S I Z E_{t}$ & $(1.84)$ & $(-0.57)$ & $(2.43)$ & $(3.99)$ \\
& 0.003 & 0.002 & 0.003 & 0.002 \\
$B M_{t}$ & $(1.33)$ & $(2.03)$ & $(1.16)$ & $(1.70)$ \\
& -0.09 & -0.03 & -0.09 & -0.03 \\
Adjusted $\mathrm{R}^{2}$ & $(-3.84)$ & $(-6.22)$ & $(-3.84)$ & $(-6.31)$ \\
$\alpha_{2}+\varphi_{1}$ & $31.55 \%$ & $47.74 \%$ & $31.81 \%$ & $48.59 \%$ \\
$p$-value: $\alpha_{2}+\varphi_{1}=0$ & -0.15 & -0.56 & -0.08 & 0.31 \\
& $<0.01$ & $<0.01$ & 0.28 & 0.30 \\
\hline
\end{tabular}

EX_PROFORMA (EX_STREET) is an indicator variable that equals one if the firm's pro forma earnings report (Street earnings forecast) for fiscal 2006 excludes stock-based compensation expense, and zero otherwise. All other variables are as previously defined. $t$-statistics in parentheses are based on standard errors clustered by firm and year. Sample of $422(1,421)$ Computer (Non-Computer) firms in 2005, in panel A, with 1,981 $(6,425)$ observations for years $t$ from 1998 to 2004, in panel B. 